\title{
Technical note: A view from space on global flux towers by MODIS and Landsat: The FluxnetEO dataset
}

Sophia Walther ${ }^{1}$, Simon Besnard ${ }^{1,2}$, Jacob Allen Nelson ${ }^{1}$, Tarek Sebastian El-Madany ${ }^{1}$, Mirco Migliavacca ${ }^{1,5}$, Ulrich Weber ${ }^{1}$, Sofia Lorena Ermida ${ }^{3,4}$, Christian Brümmer ${ }^{6}$, Frederik Schrader ${ }^{6}$, Anatoly Stanislavovich Prokushkin ${ }^{7}$, Alexey Vasilevich Panov ${ }^{7}$, and Martin Jung ${ }^{1}$

${ }^{1}$ Max-Planck-Institute for Biogeochemistry, Hans-Knöll-Straße 10, Jena, Germany

${ }^{2}$ South Pole, Digital Innovation, Fred. Roeskestraat 115, Amsterdam, The Netherlands

${ }^{3}$ Instituto Português do Mar e da Atmosfera, Rua C do Aeroporto 1749-077 Lisbon, Portugal

${ }^{4}$ Instituto Dom Luiz, Faculdade de Ciências da Universidade de Lisboa, Campo Grande Edifício C1, Piso 1, 1749-016 Lisbon, Portugal

${ }^{5}$ European Commission, Joint Research Centre, Via Fermi 2749, Ispra (VA), Italy

${ }^{6}$ Thünen Institute of Climate-Smart Agriculture, Bundesallee 65, Braunschweig, Germany

${ }^{7}$ V.N. Sukachev Institute of Forest of the Siberian Branch of Russian Academy of Sciences - separated department of the KSC SB RAS, Akademgorodok 50/28, Krasnoyarsk, Russia

Correspondence: Sophia Walther (sophia.walther@bgc-jena.mpg.de)

\begin{abstract}
The eddy-covariance technique measures carbon, water, and energy fluxes between the land surface and the atmosphere at several hundreds of sites globally. Collections of standardised and homogenised flux estimates such as the LaThuile, Fluxnet2015, National Ecological Observatory Network (NEON), Integrated Carbon Observation System (ICOS), AsiaFlux, and Terrestrial Ecosystem Research Network (TERN) / OzFlux data sets are invaluable to study land surface processes and vegetation functioning at the ecosystem scale. Space-borne measurements give complementary information on the state of the land surface in the surroundings of the towers. They aid the interpretation of the fluxes and support the training and validation of ecosystem models. However, insufficient quality, frequent and/or long gaps are recurrent problems in applying the remotely sensed data and may considerably affect the scientific conclusions drawn from them. Here, we describe a standardised procedure to extract, quality filter, and gap-fill Earth observation data from the MODIS instruments and the Landsat satellites. The methods consistently process surface reflectance in individual spectral bands, derived vegetation indices and land surface temperature. A geometrical correction estimates the magnitude of land surface temperature as if seen from nadir or $40^{\circ}$ offnadir. We offer to the community pre-processed Earth observation data in a radius of $2 \mathrm{~km}$ around 338 flux sites based on the MCD43A4/A2, MxD11A1 MODIS products and Landsat collection 1 Tier1 and Tier2 products. The data sets we provide can widely facilitate the integration of activities in the fields of eddy-covariance, remote sensing and modelling.
\end{abstract}

\section{Introduction}

The installation and maintenance of instrumental infrastructure at eddy-covariance (EC) sites worldwide require considerable financial and logistical efforts and labour force. The precious data sets of land-atmosphere fluxes and environmental conditions allow fundamental insights on ecosystem functioning (Baldocchi, 2008; Baldocchi et al., 2018; Baldocchi, 2020; Migliavacca 
https://doi.org/10.5194/bg-2021-314

Preprint. Discussion started: 25 November 2021

(c) Author(s) 2021. CC BY 4.0 License.

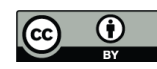

et al., 2021; Nelson et al., 2020). A significant achievement is the central processing, quality control, and open standardised distribution of a large number of the available observational records in data collections such as the LaThuile, Fluxnet2015, ABCflux (amonst others, Papale et al., 2006; Baldocchi, 2008; Pastorello et al., 2020; Virkkala et al., 2021b; Papale, 2020) to which many site teams contribute.

Complementary information from satellites or cameras (phenocams, Wingate et al., 2015) aid and refine studies of local landatmosphere interactions as they relate to ecosystem structure, phenology, and functioning and the state of the land surface (e.g., Migliavacca et al., 2015). Earth observation (EO) data for varying regional sizes around the sites can represent the actual area that contributes to the flux measurements - partly even more accurately than similar ground-based measurements can (Gamon, 2015) - provided sufficiently high spatial resolution and temporal overlap with the site-level records. Next to local studies, the combination of flux and satellite observations is also a basic ingredient for upscaling exercises of the in-situ fluxes to larger areas or even the globe (Ueyama et al., 2013; Tramontana et al., 2016; Jung et al., 2019, 2020; Joiner et al., 2018; Reitz et al., 2021; Virkkala et al., 2021a; Zeng et al., 2020).

Independent of the nature of the scientific application, the quality control and gap structure of both the EC and the EO data are the groundwork of each analysis. Different criteria help to identify problematic data points with differing levels of strictness depending on the given application. Moffat et al. (2007) and Falge et al. (2001) describe techniques to fill gaps due to missing data points in the EC data. The literature also offers a diverse set of methods to gap-fill EO data that include spatial, temporal or cross-sensor approaches (to name a few, Wang et al., 2012; v. Buttlar et al., 2014; Weiss et al., 2014; Verger et al., 2011, 2013; Kandasamy et al., 2013; Moreno et al., 2014; Moreno-Martínez et al., 2020; Yan and Roy, 2018; Ghafarian Malamiri et al., 2018; Li et al., 2018; Dumitrescu et al., 2020). The pre-processing steps are laborious and they are key to the results of the analyses. This contribution proposes a set of steps for the systematic quality assurance and gap-filling of key land surface indicators from EO data at varying resolutions. We apply them to official data products from the Moderate Resolution Imaging Spectroradiometer (MODIS) instruments and the sensors on board the Landsat satellites. Both MODIS and Landsat have long observational coverage with a high temporal overlap with most freely available EC records. Landsat measurements are of particular interest because they resolve small spatial details in pixels of $30 \mathrm{~m}$ size, but at the cost of missing out on short temporal features. The opposite is true for MODIS data products, which partly average over heterogeneous areas in spatially comparatively coarse pixels of several hundred meters. However, MODIS offers daily, partly even sub-daily temporal resolution. We process EO data sets of both surface reflectance and land surface temperature (LST) for a limited area around a given flux site. For both the quality control and the gap-filling, the approaches aim to be generalisable across all sites without accounting for specific local conditions, yet flexible enough to accurately reproduce phenological behaviour and characteristic features such as disturbances or fast transitions in managed ecosystems. The procedure shall be as simple as possible, computationally efficient and not resort to additional data sources to facilitate a potential application to EO data at global scale.

Observation geometries need special attention as the MODIS instruments measure in a wide swath to obtain high temporal coverage. They scan across their track from right to left with view zenith angles up to 65 degree from nadir. The wide range of viewing geometries leads to different fractions of surface types seen from one overpass to the next for a given site. In addition, vegetation structure and topography, together with the position of the sun relative to the sensors, cause variable shadowing 
https://doi.org/10.5194/bg-2021-314

Preprint. Discussion started: 25 November 2021

(c) Author(s) 2021. CC BY 4.0 License.

\section{(c) (i)}

effects. The reflectance product (MODIS MCD43A4, Schaaf and Wang (2015b)) partly accounts for these anisotropy effects and simulates a nadir view. In order to partly account for variability in the observed LST that is related to changing observation geometry (Rasmussen et al., 2011; Guillevic et al., 2013; Ermida et al., 2014), a correction approach developed by Ermida et al. (2018) estimates an LST offset as if the instrument would measure from directly above a site. For some applications, an oblique view might be favourable over a nadir constellation, for example to enhance the contribution of vegetation canopy to the LST estimate and minimise fractions of soil or understorey. In addition, we provide LST corrected to a viewing zenith angle of 40 degrees. In contrast to MODIS, the Landsat sensors acquire images at much smaller view angles around 7.5-degree from nadir. Ground control points and a digital elevation model help to correct for small directional effects related to terrain structure and viewing angles (Wulder et al., 2019).

The FluxnetEO products of surface reflectance, vegetation indices, and LST, that result from the proposed processing, are freely available by the services of the ICOS Carbon Portal (see data availability statement, (Walther et al., 2021a, b)). Each data set has a complementary data layer with additional flags to inform the user whether data points correspond to actual good quality observations according to the proposed criteria or whether they have been estimated in different gap-filling steps. For all sites, the FluxnetEO products cover the period 1984-2017 and 2000-2020 for Landsat and MODIS, respectively. We describe details about data inputs in section 2.2, explain the quality control and gap-filling approaches in section 3, and provide information on the resulting products in table 2 and the data availability section.

\section{Data}

\subsection{Eddy-covariance sites}

Here, we select the 338 sites from the LaThuile, Fluxnet2015 (Pastorello et al., 2020) and ICOS Drought 2018 Initiative (Drought 2018 Team and ICOS Ecosystem Thematic Centre, 2020) flux data releases. Site coordinates given in different sources (Ameriflux, Asiaflux, Europe-Fluxdata, Fluxdata.org, and a previously compiled in-house Fluxnet-site location list) may differ. In that case, the coordinates with the highest precision were selected. In case the coordinates differed by more than $0.001^{\circ}$ for a given site, a manual check in Google Earth identified the correct or most probable location of the site. The final set of 338 sites for which we process the MODIS and Landsat EO data is listed in table A1. Forests and grasslands are best represented among the 338 sites. The collection includes fewer sites from savannas and shrublands, and only one site from a deciduous needleleaf forest (table 1).

\subsection{MODIS and Landsat}

The MCD43A4 product combines AQUA and TERRA observations and provides estimates of surface reflectance in the MODIS bands 1-7 (Schaaf and Wang, 2015b). Time series represent observations modelled at nadir view at a resolution of 16 days and $500 \mathrm{~m}$ spatial pixels. For the quality control of MCD43A4, a complementary product, MCD43A2, contains band 
https://doi.org/10.5194/bg-2021-314

Preprint. Discussion started: 25 November 2021

(c) Author(s) 2021. CC BY 4.0 License.

(c) (i)

Discussions

Table 1. Representation of different plant functional types and Koeppen climate classes across the 338 sites in the FluxnetEO collection.

\begin{tabular}{cclc}
\hline plant functional type & number of sites & Koeppen main climate & number of sites \\
\hline evergreen needleleaf forest (ENF) & 86 & arid & 26 \\
evergreen broadleaf forest (EBF) & 25 & equatorial & 23 \\
deciduous needleleaf forest (DNF) & 1 & warm temperate & 171 \\
deciduous broadleaf forest (DBF) & 40 & snow & 12 \\
mixed forest (MF) & 13 & polar & 3 \\
woody savanna (WSA) & 10 & undefined & \\
savanna (SAV) & 11 & & \\
closed shrubland (CSH) & 6 & & \\
open shrubland (OSH) & 19 & & \\
grassland (GRA) & 58 & & \\
crops (CRO) & 36 & & \\
wetlands (WET) & 32 & & \\
snow (SNO) & 1 & \\
\hline \hline
\end{tabular}

specific information on the quality of the inversion of the bidirectional reflectance distribution function as well as snow cover, platform information and land/water coverage in the scene (Schaaf and Wang, 2015a).

The MODIS MOD11A1 (TERRA, starting in 2000) and MYD11A1 (AQUA, starting in 2002) products (hereafter jointly referred to as MxD11A1, Wan et al. (2015a, b)) provide daily LST and emissivity estimates aligned with quality and view angle information at $1 \mathrm{~km}$ spatial pixel sizes. The LST values represent instantaneous values and are selected based on viewing zenith angle and LST values (MOD11A1 user guide, https://lpdaac.usgs.gov/documents/118/MOD11_User_Guide_V6.pdf). Four LST data streams are available: TERRA $A_{\text {day }}$ with observations around 10.30 am local time, $\mathrm{AQUA}_{\text {day }}$ with observations around $1.30 \mathrm{pm}$, TERRA $_{\text {night }}$ around $10.30 \mathrm{pm}$ and $\mathrm{AQUA}_{\text {night }}$ around $1.30 \mathrm{am}$. For each of them, observation times vary between overpasses by about \pm 1.5 hours.

Reflectance-based Landsat time series comprise the entire multi-temporal collection 1 of the Landsat 4, 5, 7 and 8 archives (https://landsat.gsfc.nasa.gov/data) covering the period 1984-2017 at $30 \mathrm{~m}$ spatial pixel size. The seven spectral bands of the Landsat product were collected: BLUE, GREEN, RED, near infrared (NIR), shortwave infrared 1 and 2 (SWIR1, SWIR2), and thermal infrared (TIR) (https://landsat.usgs.gov/what-are-band-designations-landsat-satellites). Landsat data have been pre-processed using the Landsat Ecosystem Disturbance Adaptive Processing System (LEDAPS, Schmidt et al., 2013) and the Landsat Surface Reflectance Code (LaSRC, https://landsat.usgs.gov/landsat-surface-reflectance-data-products) for atmospheric correction. The pixelQA layer contains information related to clouds, cloud shadows, snow, and ice and is useful for the quality control of the Landsat data (Zhu and Woodcock, 2012; Zhu et al., 2015). 
https://doi.org/10.5194/bg-2021-314

Preprint. Discussion started: 25 November 2021

(c) Author(s) 2021. CC BY 4.0 License.

(c) (i)

The services by Google Earth Engine (Gorelick et al., 2017) provided cutouts of the above mentioned products at the EC sites. Independently of the product and its spatial resolution, the cutout area was limited to a maximum distance of $2 \mathrm{~km}$ between a given tower and the centre of a given satellite pixel. Downloading the EO data in tiff-format avoided intransparent reprojection of the data from sinusoidal to regular grid by Google Earth Engine, which would have been problematic for the quality flags in the MCD43A2 and MxD11A1 products. The Landsat data were already provided in regular grid by Google Earth Engine.

\section{Methods}

Data processing works separately for each pixel in a cutout (henceforth subpixel). We describe here the overall concept and rationale of the quality filter and the gap-filling, but report all technical details in the Appendix B.

\subsection{Processing steps of reflectance-based indicators}

\subsubsection{Quality control and computation of spectral indices}

Quality control of the MODIS reflectance-based vegetation indices focused on three aspects: good inversion quality of the bidirectional reflectance distribution function as indicated by the BRDF_Albedo_Band_Quality_Bandx flags in the MCD43A2 product, snow-free conditions according to the Snow_BRDF_Albedo flag, and the omission of reflectance values that are affected by the presence of water in the field of view using the BRDF_Albedo_LandWaterType flag. For the selected data samples which passed those criteria we computed a large set of spectral vegetation indices (table 2). An additional check removed possible values of the vegetation indices outside their defined ranges. Some of the time series contained obvious outlier values. We employed an empirical filter which largely removed those samples which had a particularly large difference to the median of their surrounding values in a temporal window (Papale et al., 2006, technical details on all filters in Appendix B).

In the Landsat data, the flag pixel_qa provided quality attributes (CFMask, Foga et al., 2017) and removed pixels that contained snow/ice, cloud, and/or cloud shadow using a binary flag of presence. Similar to the MODIS product, we computed a series of spectral vegetation indices (table 2) using the good quality observations and removed possible values of the indices outside their defined ranges. A slightly modified filter removed possible outlier values also for the Landsat data (see details in Appendix B.)

\subsubsection{Gap-filling}

In the literature several gap-filling and smoothing approaches are available which work in one or more dimensions (e.g., Wang et al., 2012; Kandasamy et al., 2013; v. Buttlar et al., 2014; Weiss et al., 2014; Yan and Roy, 2018; Zhang et al., 2021) or use fusion methods between sensors (Verger et al., 2011; Moreno-Martínez et al., 2020). They differ in their levels of sophistication and computational efforts. One of our requirements for the gap-filling approach was that is employs exclusively 
https://doi.org/10.5194/bg-2021-314

Preprint. Discussion started: 25 November 2021

(c) Author(s) 2021. CC BY 4.0 License.

\section{(c) (i)}

temporal operations and does not use additional data sources. This allows the gap-filling to be generally applicable to a single time series per site, to several subpixels in a cutout around a site and also to global EO data. The idea was to retain the good quality data and make as realistic estimates as possible for the gaps between them instead of representing a gap-free time series from fitting functions to the valid data. The following recipe describes the steps to estimate missing data points conceptually, all technical details we report in Appendix B:

1. Fill short non-snow related gaps ( $\leq 5$ days or $\leq 1$ month for MODIS and Landsat, respectively) with a median across valid values in moving windows of 16 days ( 3 months for Landsat). The moving median only fills gaps, it does not change/ smooth valid data points.

2. Fill snow related gaps with a constant baseline value which is identified as the average of valid data points adjacent to snow covered periods, i.e. immediately before snow fall or after snow melt (after Beck et al., 2007, but see details in Appendix B). Consider all times with a snow flag larger than 0.1 or missing snow information as snow covered. The latter periods are included as the snow flag appears to systematically miss snow periods in higher latitudes in the beginning of the winter. Still, frequent gaps with missing snow information also occur during the growing season. In order to avoid wrong filling with a constant value during the growing season this gap-fill step is not applied when the probability of snow cover is low, i.e. when the average seasonal cycle indicates typically snow-free conditions at a given time of the year, or when typically no snow occurs at all at a given site.

3. Subsequently, another moving median in windows of 40 days ( 4 months for Landsat) fills gaps shorter than 65 days ( 2 months for Landsat).

4. Compute the median seasonal cycle and use it to fill longer gaps by linearly scaling it to the time series in temporal windows. This windowed operation guarantees more flexibility to correctly represent inter-annual variations in the time series and might even partly account for changes in the shape of the seasonal cycle due to disturbances. It is, however, not suited to fill regularly recurring gaps at a certain time of the year, e.g. during rain seasons (Verger et al., 2013).

5. Fill the remaining gaps by piecewise cubic polynomial interpolation. Time series with less than 300 valid data points in the whole record after application of all the previous gap-filling steps will not be meaningful for analysis but are still filled by nearest neighbour interpolation.

6. Temporal operations cannot meaningfully fill gaps at the beginning and at the end of the record. Therefore the first/last valid data points are repeatedly appended at the beginning/end of the record.

The described processing steps are generalisable across a range of spectral vegetation indices and can reliably fill missing data points across sites globally (see examples in section 4). However, a number of sites have extremely low data availability after quality checks, and the gaps in their time series are challenging to temporally interpolate in a meaningful way. This can lead to problematic gap-filled data points whose reliability and realism are questionable. Examples are tropical sites and/ or sites with a pronounced wet season with permanent cloud cover. The same generally applies for MODIS in the years 
https://doi.org/10.5194/bg-2021-314

Preprint. Discussion started: 25 November 2021

(c) Author(s) 2021. CC BY 4.0 License.

(c) (i)

2000-2002 when observations stem mainly from the TERRA satellite and therefore data availability is comparatively low. For Landsat, the number of available scenes is relatively heterogeneous across the globe (https://www.usgs.gov/media/images/ cumulative-number-scenes-landsat-archive) with some regions having a very good coverage (e.g., North America) while other regions are observed less frequently (e.g., Russia and Africa). Such differences in the availability of good quality data between sites strongly affect the quality of the gap-filling at site level. FluxnetEO therefore provides for each data layer a gap-fill flag which describes whether and if so, how a certain data sample has been imputed which allows users to explore individual sites and use (parts of) the gap-filled data or resort to only using the high quality original data points.

\subsection{Preprocessing of MODIS land surface temperature}

\subsubsection{Quality checks}

The quality control of the MODIS LST did not use the flags provided in the MxD11A1 products, but focussed on the removal of outlier values. Negative outlier values in LST might represent residual cloud contamination, whereas unusually high values might originate from undetected saturation in the level 1 data. Empirical quality checks followed the procedure for the MODIS reflectances, i.e. they discarded data points that deviated strongly from the median of their surrounding values in temporal windows of 30 days (Papale et al., 2006). An additional sanity check eliminated any daytime LST that was lower than the minimum of AQUA and TERRA nighttime LST for a given day.

\subsubsection{Geometrical correction}

For several applications, variable viewing geometries as inherent in the MODIS LST observations are not desirable. A geometrical correction approach developed by Ermida et al. (2018) accounted for directionality in LST retrievals due to vegetation structure and topographical effects. A parametric model estimates the magnitude of LST as if constantly observed from nadir or from an angle of 40 degrees between the sensor and the zenith above a given site. Ermida et al. (2018) derived the coefficients for this geometrical model at a resolution of 0.05 degree. We followed the pragmatic approach of selecting the model coefficients for the correction from the pixel containing a given site, and acknowledge that we did not investigate to what extent the given site conditions represent the overall characteristics of the land surface in the allocated pixel. Further input to the geometrical model were the viewing azimuth angles, solar angles at the overpass time and estimates of daily potential radiation at the top of the atmosphere. The geometrical correction was applied to each subpixel in a cutout separately.

\subsubsection{Gap-filling}

Also for the gap-filling of LST several approaches are present in the literature (e.g., Gerber et al., 2018; Ghafarian Malamiri et al., 2018; Li et al., 2018; Dumitrescu et al., 2020). When using exclusively operations in time and no ancillary data to estimate invalid LST observations, one needs to take care to respect the shorter autocorrelation of LST compared to the reflectance-based indicators. According to Vinnikov et al. (2008) the weather-related component of clear-sky LST has an autocorrelation of about 3 days. The following sequence of steps filled the four MODIS LST data streams (for technical details refer to Appendix C): 
https://doi.org/10.5194/bg-2021-314

Preprint. Discussion started: 25 November 2021

(c) Author(s) 2021. CC BY 4.0 License.

(c) (i)

1. Similar to the reflectances, a first step consisted in a temporal moving median to fill gaps, but in shorter windows of eight days.

2. A second step was inspired by Li et al. (2018) and Crosson et al. (2012) and foresaw to use one of the four MODIS LST time series as a 'reference' to fill gaps in a second 'imputed' one. We computed a median seasonal cycle of the difference of the 'reference' and the 'imputed' MODIS LST. This average shift was linearly scaled to the actual shift in temporal windows. The sum of the scaled average shift and the 'reference' LST filled gaps in the 'imputed' LST time series. This procedure iteratively used three of the MODIS LST data streams to fill the fourth, i.e. each one is imputed once by all three others (see details in Appendix C). This gap-fill step was only possible in cases where not all four MODIS LST observations were invalid during a given day, but extremely advantageous to preserve short synoptic variability in the gap-fill estimates.

3. In fully cloudy days without any valid LST observation, or in case a period has too few valid observations for a meaningful calibration of the linear model in the previous step, the gap-filling followed the same steps like for the reflectancebased spectral indices:

Linearly scale the valid LST observations of each of the four data streams to their own median annual cycle in temporal windows.

4. Interpolate the remaining gaps with cubic polynomials, or nearest neighbour in case of very low data availability (less than 300 valid data points in an entire time series).

5. Missing values at the beginning and the end of the record cannot be meaningfully filled by temporal methods and are therefore simply repeated.

Steps 3-5 produced very smooth and therefore less realistic LST estimates than steps 1-2. Also, one needs to be aware that any LST estimate in data gaps from this procedure necessarily represents an LST estimate under clear sky conditions, which can be very different from the real LST under overcast skies (Ermida et al., 2019). This needs to be considered for a given application to prevent effects of clear-sky bias in the LST data sets on the results. Like for the vegetation indices, also the LST data layers have a gap-fill flag in FluxnetEO describing which data points are original and which gap-filling step filled the missing values. 
https://doi.org/10.5194/bg-2021-314

Preprint. Discussion started: 25 November 2021

(c) Author(s) 2021. CC BY 4.0 License.

(c)

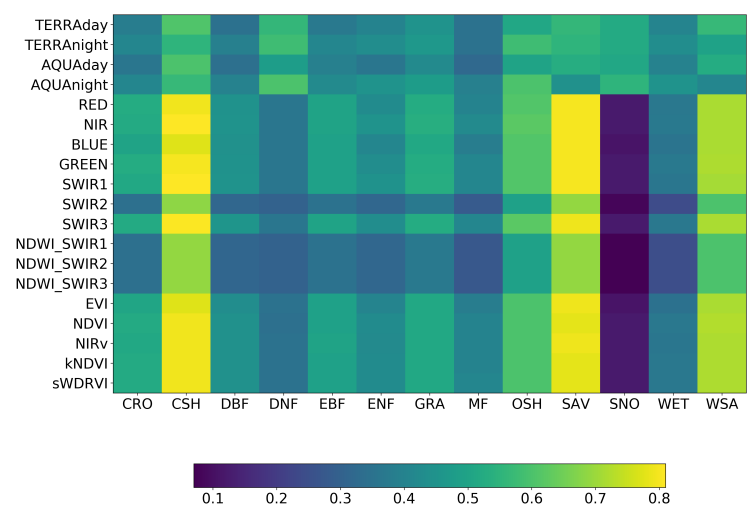

Figure 1. Fraction of good quality data in the MODIS time series. Colours represent the median data availability in tower pixels across sites grouped by plant functional type for 2003-2020 (the time period when both TERRA and AQUA satellites are in space).

\section{Results and Discussion}

\subsection{Gap-statistics across indices}

Data availability after quality screening is highly variable between sites and depends on the data stream (Fig. 1). MODIS LST generally has less valid data points among the data sets than the reflectance-based indicators, and often less during daytime than nighttime. While the LST are instantaneous values, the reflectances represent averages over 16-day periods. A lower number of good quality observations in indices that rely on band 6 relate to degraded detectors in AQUA MODIS band 6. Large differences in the amount of good quality data between groups of plant functional types, especially for the reflectances, mirror general atmospheric conditions in different regions.

\subsection{Temporal patterns of the gap-filled time series}

230 We illustrate some characteristics of the MODIS time series in FluxnetEO using example sites. The Austrian site Neustift (AT-Neu) was situated in a valley in the Alps and surrounded by grasslands which were typically mown three times a year (Wohlfahrt et al., 2008). According to their nature, the LST time series exhibit faster variability than the vegetation indices (Fig. 2). Midday observations (AQUAday) partly show an LST increase after the first harvest event in a year around the day of the year 150. The MSC of most vegetation indices clearly marks the mowing timing, although the relative magnitude varies between indices. Constant values in winter represent snow-covered times.

Focusing on the example of the MODIS EVI, other sites illustrate a few characteristics of the gap-filling procedure in more detail (Fig. 3): At the evergreen needleleaf forest site El Saler in Spain (ES-ES1) much data passes the quality control 

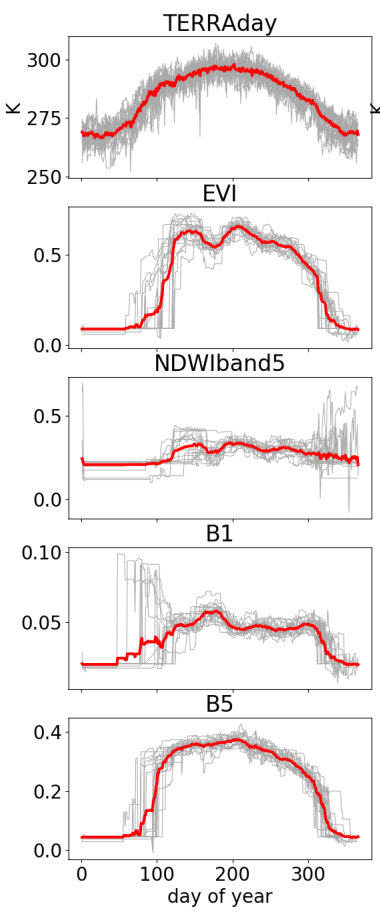
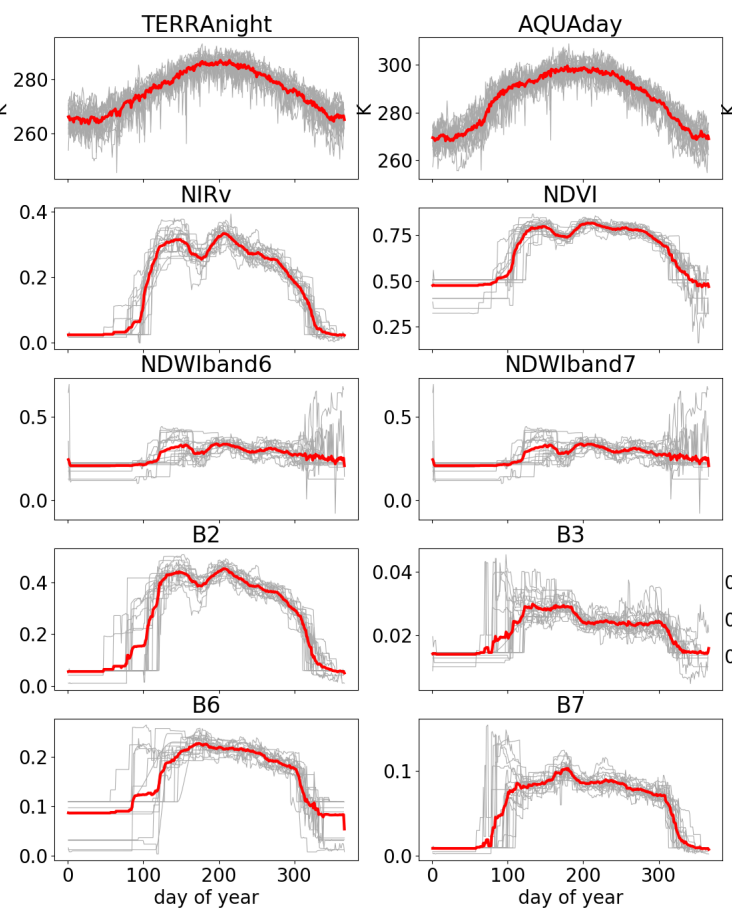
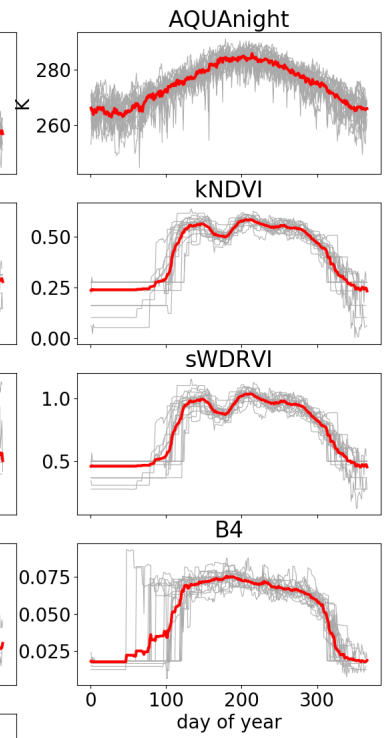

Figure 2. Median seasonal cycle (red) and individual yearly trajectories (gray) of the LST (top row) and vegetation indices and surface reflectance (second to last rows) in the pixel containing the Austrian site Neustift (AT-Neu).

and mostly short gaps are reliably filled also in the absence of a very regular seasonal cycle in EVI. The boreal forest site Saskatchewan (CA-SF1) illustrates the effect of a disturbance that happened in 2015 (though the site was operated only until 2006). The gap-filling procedure adapts to the modified conditions both abruptly when the disturbance happens and gradually during recovery in the following years. There is a problematic group of high EVI values during winter 2006/07. The moving window outlier filter applied to the MODIS reflectances is by design unable to detect those outliers as they occur consecutively in a short period of time. In Tharandt (DE-Tha, evergreen needleleaf forest) and Lonzee (BE-Lon, crops), data are scarce in the years 2000-2002 where only TERRA was in operation and the estimated values are less reliable. Also, false filling by the snow baseline value during the growing season could not entirely be prevented, causing an unrealistic dip in one year in each of the sites. Note that the snow flag contains partly long data gaps in CA-SF1, DE-Tha and BE-Lon. Finally, the woody savanna site Adelaide River (AU-Ade) is a typical example of EC sites in climates with a dry and a wet season. While in the dry season basically no data gaps occur, cloud coverage in the rainy season is long enough such that mainly the last gap-filling steps of a linearly scaled MSC and interpolation take effect. Although the scaling of the MSC does not fully succeed in all years to produce smooth transitions between the good quality data and the gap-filled ones, the interpolation is able to preserve 

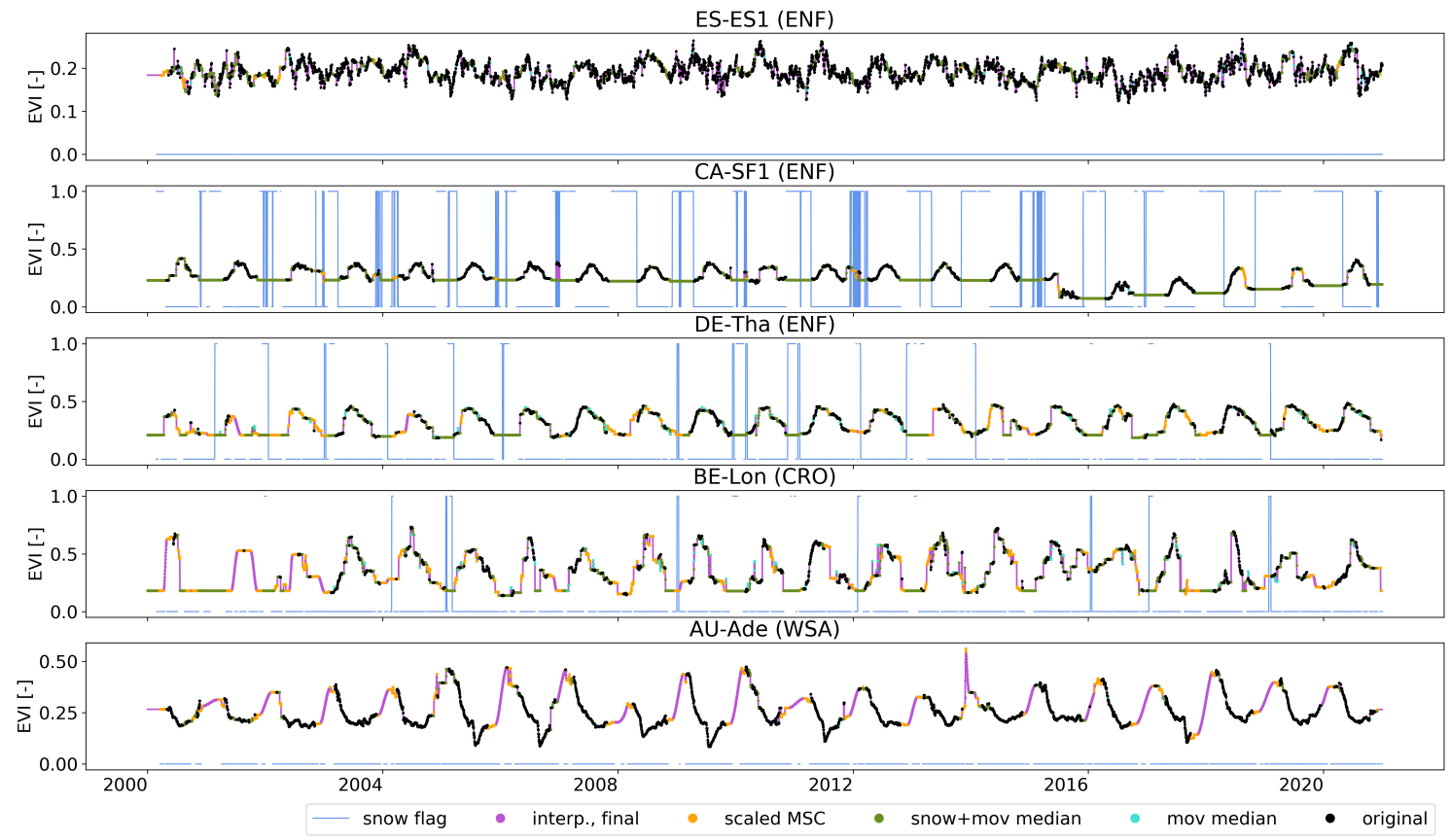

Figure 3. Illustration of gap-filling steps in the pixel containing selected eddy-covariance sites for the MODIS EVI.

inter-annual variations in the EVI.

Missing LST values were estimated most reliably in the gap-filling steps 1-2 (moving median and scaled average shift to observations at other overpass times) because the typical short-term variability in the time series could be preserved. In the Spanish site Majadas de Tietar (ES-LMa, Fig. 4 top panel), savanna-type vegetation is prevalent with a dry summer and wet winter. Visually the gap-filling procedure succeeds in preserving the typical higher LST variability in the dry season and seasonally changing diurnal amplitudes. Also, in Saskatchewan (CA-SF1) gap-filling step 2 successfully estimates the largest fraction of missing values for each data stream from the complementary observation times. The EVI indicated a disturbance event in the beginning of 2015 (Fig. 3) that continued to strongly affect the EVI also in the following year. The event also marks the LST time series in that daytime LST, and therefore, the diurnal amplitude clearly increase in summer after 2015. The gap-filling procedure follows this behaviour. Relative to Majadas de Tietar or Saskatchewan, in the mixed forest in Vielsalm (BE-Vie), data gaps are much more persistent throughout a day and the gap-filling works more often with the third gap-filling step using an average seasonal cycle of LST to estimate missing observations. Finally, at the woody savanna site Howard Springs in northern Australia (AU-How, Fig. 4 bottom panel) there is a strong seasonal phasing between daytime and nighttime LST. Data availability also changes with the seasons. In the monsoon season, synoptic variability in the filled data points 
https://doi.org/10.5194/bg-2021-314

Preprint. Discussion started: 25 November 2021

(c) Author(s) 2021. CC BY 4.0 License.

(c) (i)
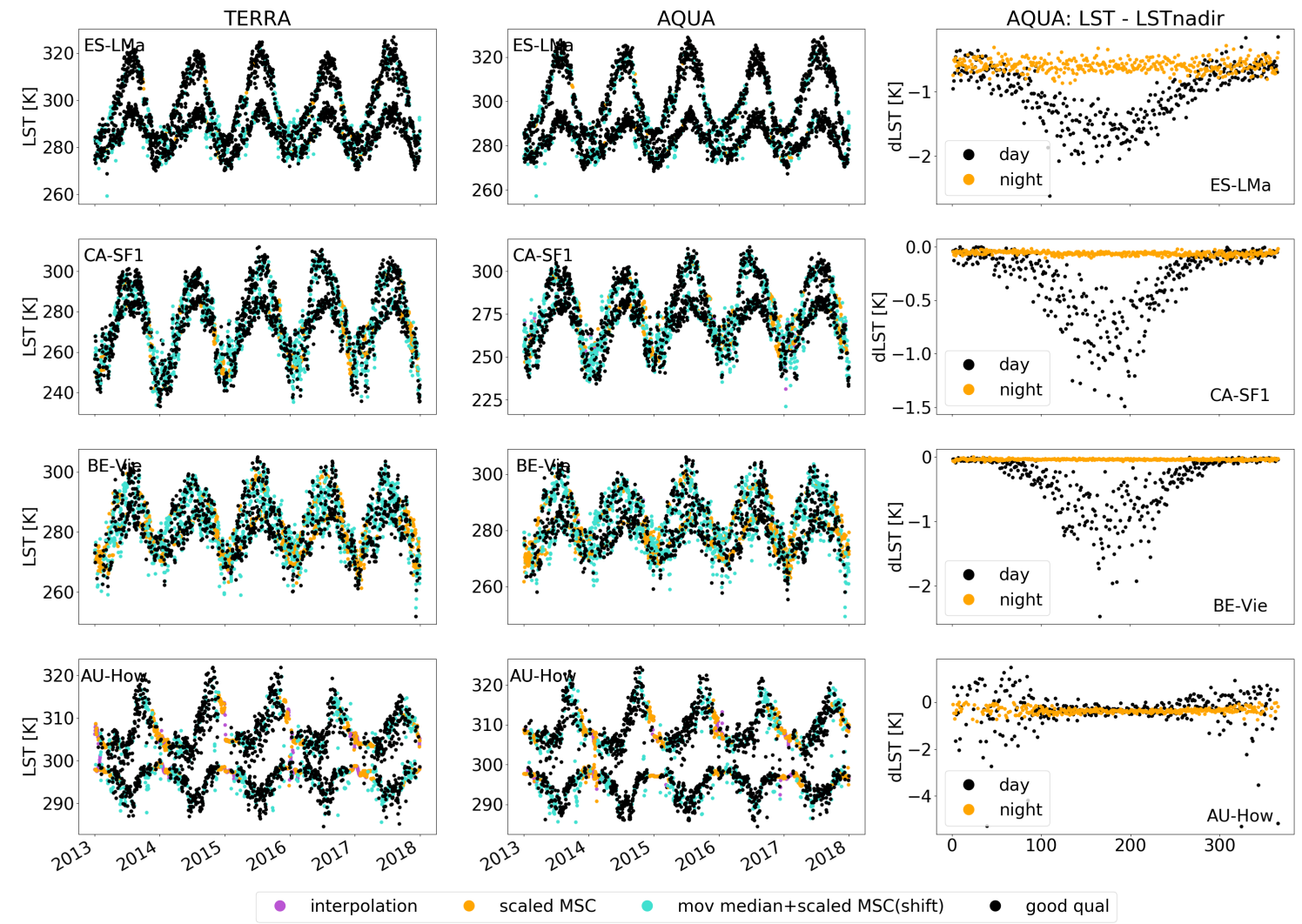

Figure 4. LST gap-filling steps in the pixel containing selected eddy-covariance sites for daytime and nighttime LST. The rightmost column shows the average annual cycle of the correction factor between LST from variable viewing angles and LST corrected to nadir view.

is unrealistically low because the gap-filling needs to resort to filling by a median seasonal cycle of LST (obtained from those years in which the monsoon starts late) or by interpolation.

Geometrical corrections to nadir viewing angle are much larger and have a stronger seasonality for daytime LST than for nighttime observations (rightmost panel in Fig. 4, Ermida et al. (2018)). The daytime LST value from a nadir view is consistently estimated to be several Kelvin higher than from an oblique view. The Australian Howard Springs is an exception in that the correction offset to nadir has no consistent sign during the wet season . 


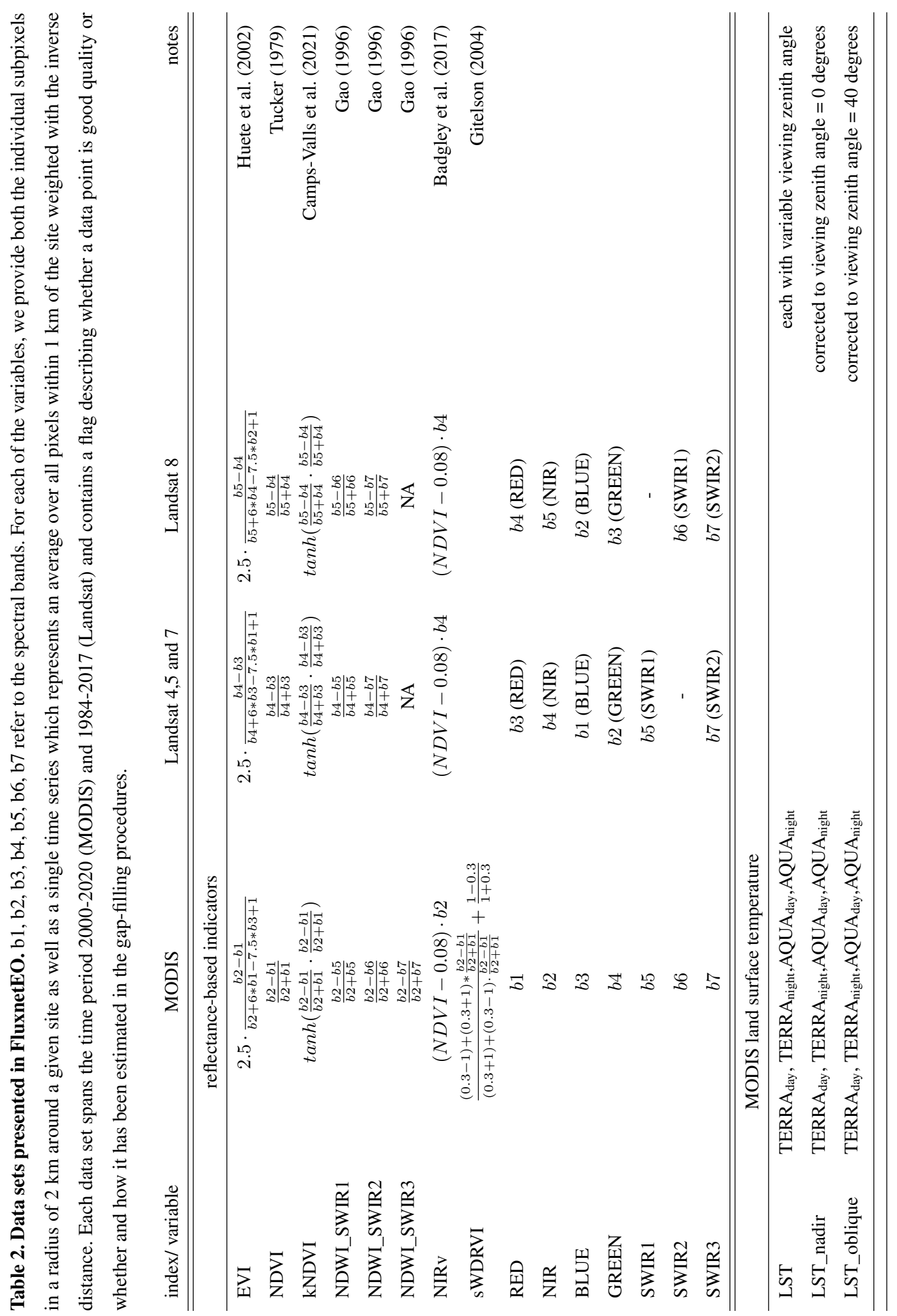


https://doi.org/10.5194/bg-2021-314

Preprint. Discussion started: 25 November 2021

(c) Author(s) 2021. CC BY 4.0 License.

\section{(c) (i)}

\subsection{On the importance of spatial context}

The type and distribution of the vegetation around a given EC measurement station are not necessarily homogeneous. Instead, clusters of different vegetation or land use types might prevail in different sections of the immediate surroundings of a site. The area that a given flux measurement is representative of (the flux footprint, Schmid, 1997) changes rapidly with wind direction, turbulence conditions, atmospheric stability, and surface resistance (Schmid, 1997; Vesala et al., 2008; Chu et al., 2021). An exact match between the flux footprint and EO data (or a model grid cell) is challenging due to the often unknown or uncertain flux footprints and coarse spatial grid sizes. The scale mismatch is equally important in validation exercises for site-level measurements of surface reflectance (Román et al., 2009; Cescatti et al., 2012), site-level energy-balance closure (Stoy et al., 2013) and model-data integration (Williams et al., 2009). The role that the scale-mismatch between site-level and EO data plays for ecosystem analyses clearly depends on the site and the application. Some applications try to account for the mismatch (Pacheco-Labrador et al., 2017; Wagle et al., 2020), others ignore it and use a custom area around each EC site. Approaches to quantify and account for heterogeneity within a satellite pixel or a certain area around a given site do exist in the literature (Román et al., 2009; Chu et al., 2021; Duveiller et al., 2021), but seem less exploited. In this section, we present different examples for the relevance of spatial context. We computed the average flux footprints for every day (MODIS) and month (Landat) around three example EC stations (Majadas de Tietar, ES-LM1, Gebesee, DE-Geb, and Zotino, RU-Zo2). We illustrate how the relationship between EC-derived gross primary productivity (GPP) and EVI as an EO-derived proxy of the same changes according to whether the footprint area is taken into account or custom cutout sizes are chosen. In RU-Zo2, we compare surface temperature inverted from long-wave outgoing radiation to LST and illustrate how the pixel sizes relate to the flux footprint area (see details on the data processing in Appendix D).

The site ES-LM1 (El-Madany et al., 2018) is a tree-grass ecosystem which is very homogeneous at the remote sensing scale (pixels $>=20 \mathrm{~m}$ ). While the trees are evergreen, the herbaceous layer senesces in summer and re-greens in winter (Luo et al., 2018). The EO cutout of $2 \times 2 \mathrm{~km}^{2}$ includes irrigated agricultural areas north of the flux footprint. These fields are barren in winter and are covered with crops in summer. MODIS and Landsat EVI are strongly negatively correlated to GPP derived from EC in the pixels over agricultural areas, as are the anomalies of EVI and GPP (Fig. D1 a-d). Conversely, high positive correlations prevail across the remaining larger parts of the EO cutouts. Landsat EVI overlaid by the average flux footprint for two example months illustrates that the EC GPP is only representative of the tree-grass ecosystem (Fig. 5e, g). Hence, the spatial representativeness of EO data for EC fluxes might differ strongly depending on which satellite pixels are chosen for the analysis. We computed the average EVI that is representative of the flux footprint (henceforth fpa for footprint area). We compared it with an average EVI weighted with the probability density function of the flux footprint in order to take into account the decreasing influence of subpixels further away from the tower (henceforth fpw for weighted footprint area), as well as with two pragmatic approaches in case a flux footprint is unknown: an EVI average over all subpixels in the cutout with a radius of $2 \mathrm{~km}$ (henceforth fex for full extent) or only the single subpixel that contains the tower (cpx for center pixel). The most noticeable difference between the time series for the different intersection methods is that the full extend (fex) in both 
https://doi.org/10.5194/bg-2021-314

Preprint. Discussion started: 25 November 2021

(c) Author(s) 2021. CC BY 4.0 License.

\section{(c) (i)}

Landsat and MODIS EVI is comparatively lower during the winter period (Fig. 5a,c). The agricultural areas contribute to fex, while the footprint intersection methods (fpa and fpw) and the center pixel (cpx) EVI consistently indicate high greenness in the tree-grass ecosystem.

Gebesee, DE-Geb, is an agricultural site. The common approach in conducting EC measurements is to put the tower in a location where the land use is as homogeneous as possible, to be able attribute fluxes to a targeted ecosystem, e.g. a known crop type. In Gebesee, this was assured for most of the years in the long site history (e.g. Fig. 5h), but not from 2011-2013. In these years, the field was split into two different adjacent crop types that contributed to the measured fluxes (Fig. 5f), raising the risk for pitfalls in the analyses of the fluxes. Also, in situations/ years when the flux footprint represents a single field, additional potential difficulties originate from phenological differences between fields within the EO cutouts (Fig. 5f,h) if not properly matched. For example, the anomalies of both GPP and EVI are only highly correlated with each other in the immediate surroundings of the tower (Fig. D1g-h). Phenological heterogeneity between fields might explain why the EVI averaged over the full cutout (fex) is clearly different from the EVI in the footprint area (fpa, fpw) or the tower pixel (cpx) during the growing season maxima in 2015/16 (Fig. 5b,d). Also, consistently with the GPP, the EVI in the tower pixel indicates slightly later senescence in 2017 than averaged over the footprint area or the full cutout, highlighting considerable effects of a mismatch between the flux footprint and the EO area.

Irrespective of the match between flux footprint and the area that the EVI is representative of, Fig. 5 illustrates the complimentarity between MODIS and Landsat in terms of resolution. Although Landsat offers high spatial detail, the temporal patterns that can be resolved with monthly averages are much coarser than the shorter variations that daily MODIS data can describe. Depending on the application the user of FluxnetEO might choose one or the other.

RU-Zo2, the Zotino tall tower observatory ZOTTO, is located in the taiga-tundra transition zone. The landscape in the proximity of the EC station is a heterogeneous mix of forest, bogs and wetlands. At the tall tower, fluxes are measured at different heights above the canopy. The size of the flux footprint strongly increases with height and the fluxes at the highest level partly represent areas more than $2 \mathrm{~km}$ away from the site (Fig. 6b-d). Flux footprints of measurements closer to the canopy are usually much smaller than the MODIS pixel size of $1 \mathrm{~km}$ for the LST, but the flux footprints of the higher measurement levels at RUZo2 partly integrate over multiple of such pixels. Size and direction of the footprint extents strongly vary over time (note that Fig. 6b-d represent three consecutive days), such that the vegetation types and surface conditions sampled do not only differ between measurement heights but also between days. We compare spaceborne LST AQUA $A_{\text {day }}$ integrated over the flux footprint area $\left(\mathrm{LST}_{\mathrm{fpa}}\right)$ with surface temperature inverted from long-wave outgoing radiation measured at the tower for clear-sky days (Fig. 6a, see details about the methods in Appendix D). $\mathrm{LST}_{\mathrm{fpa}}$ of all three heights is consistently about $30 \%$ higher than the inverted surface temperature for most of the year, with a notably higher scatter under freezing conditions. The slope between $\mathrm{LST}_{\mathrm{fpa}}$ and surface temperature markedly decreases for the highest temperatures, which might indicate significant changes in surface emissivity during the brief peak growing season when vegetation extent is highest and the surface has drained from snow melt. 

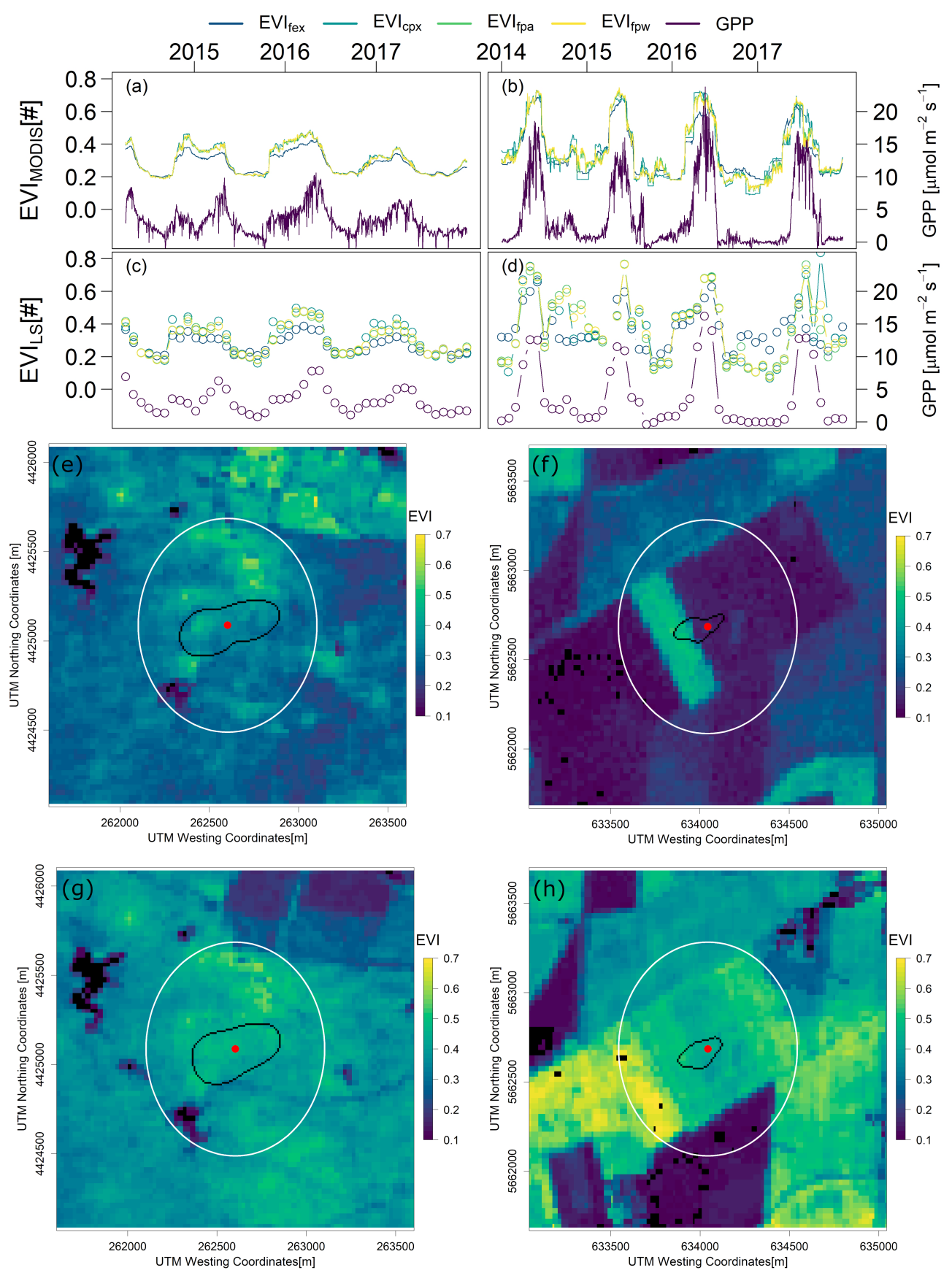

Figure 5. Time series of EVI and GPP for ES-LM1 (a,c) and DE-Geb (b,d). MODIS EVI (top row) and Landsat EVI (second row) represent areas with different extents: full extent of the cutout $\left(\mathrm{EVI}_{\mathrm{fex}}\right)$, the center pixel that contains a tower $\left(\mathrm{EVI}_{\mathrm{cpx}}\right)$, the EVI averaged over the flux footprint area $\left(\mathrm{EVI}_{\mathrm{fpa}}\right)$, and the $\mathrm{EVI}_{\mathrm{fpa}}$ weighted with the flux probability density function $\left(\mathrm{EVI}_{\mathrm{fpw}}\right)$. Subplots e-h: Landsat EVI overlaid with the monthly flux footprint (black line) for ES-LM1 in November 2014 (e) and April 2016 (g), and for DE-Geb in February 2012 (f) and February 2016 (h). Non-original low quality EVI values are blacked out. Red circles indicate the location of the EC station, white circle denotes $1 \mathrm{~km}$ diameter from the station. 

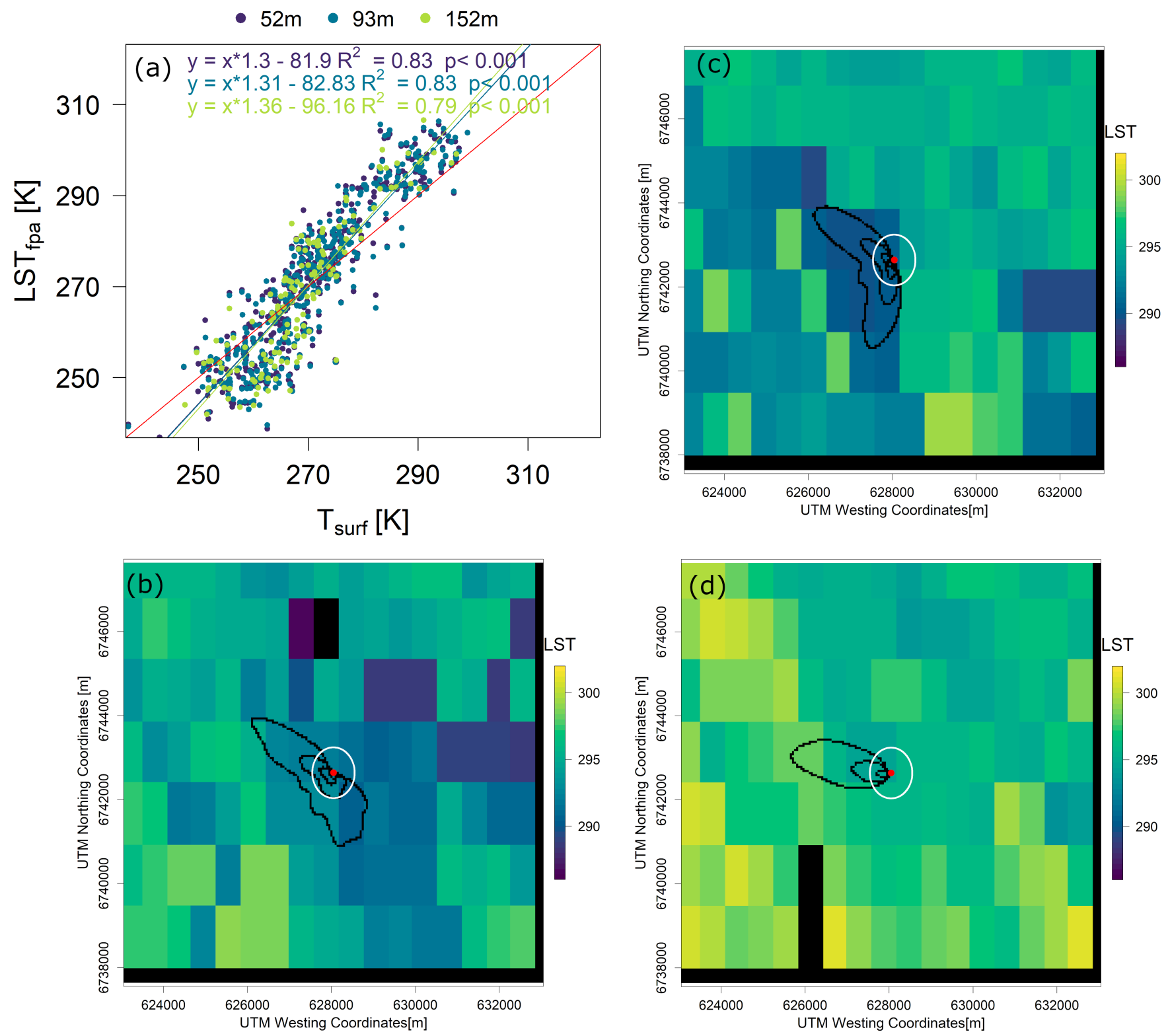

Figure 6. Relationship between MODIS AQUA $\mathrm{day}_{\mathrm{f}} \mathrm{LST}_{\mathrm{fp}}$ and surface temperature calculated from the long-wave outgoing radiation at $302 \mathrm{~m}$ above ground (details about the methods in Appendix D). The red line represents the 1:1 line. Subplots b to d show example footprints at the three levels (black lines) overlaid on the LST map from May 31st to June 2nd, 2017, respectively. Non-original low quality LST values are blacked out. The white circle indicates the $1 \mathrm{~km}$ diameter around the tower. 
https://doi.org/10.5194/bg-2021-314

Preprint. Discussion started: 25 November 2021

(c) Author(s) 2021. CC BY 4.0 License.

(c) (1)

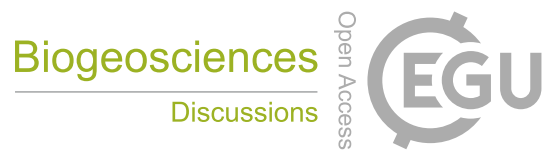

Next to matching the flux footprints with the EO data pixels, spatial context is equally important in studies of vegetation recovery after a disturbance event. The Sky Oaks-Young Stand (US-SO3) is a closed shrubland with woody vegetation less than $2 \mathrm{~m}$ tall. The US-SO3 site experienced a fire during the period 2002-2003, followed by regrowth. Landsat allows to observe

345 the impact structure and the spatially very heterogeneous recovery dynamics with remarkable detail (Fig. 7): The fire caused lower than average EVI in large parts of the cutout during the period 2002-2004 (Fig. 7d-f). From 2005 onwards, some patches, particularly the western part of the cutout, appear to have recovered faster from the disturbance than other patches (Fig. 7g). By 2011, EVI has reached pre-fire values in most parts of the area around the site with only small patches as exceptions indicating that regrowth was complete (Fig. 7n). This example illustrates how high spatial resolution EO combined with EC at the sitelevel can provide complementary insights for better understanding disturbance regimes and the associated recovery dynamics. 
https://doi.org/10.5194/bg-2021-314

Preprint. Discussion started: 25 November 2021

(c) Author(s) 2021. CC BY 4.0 License.
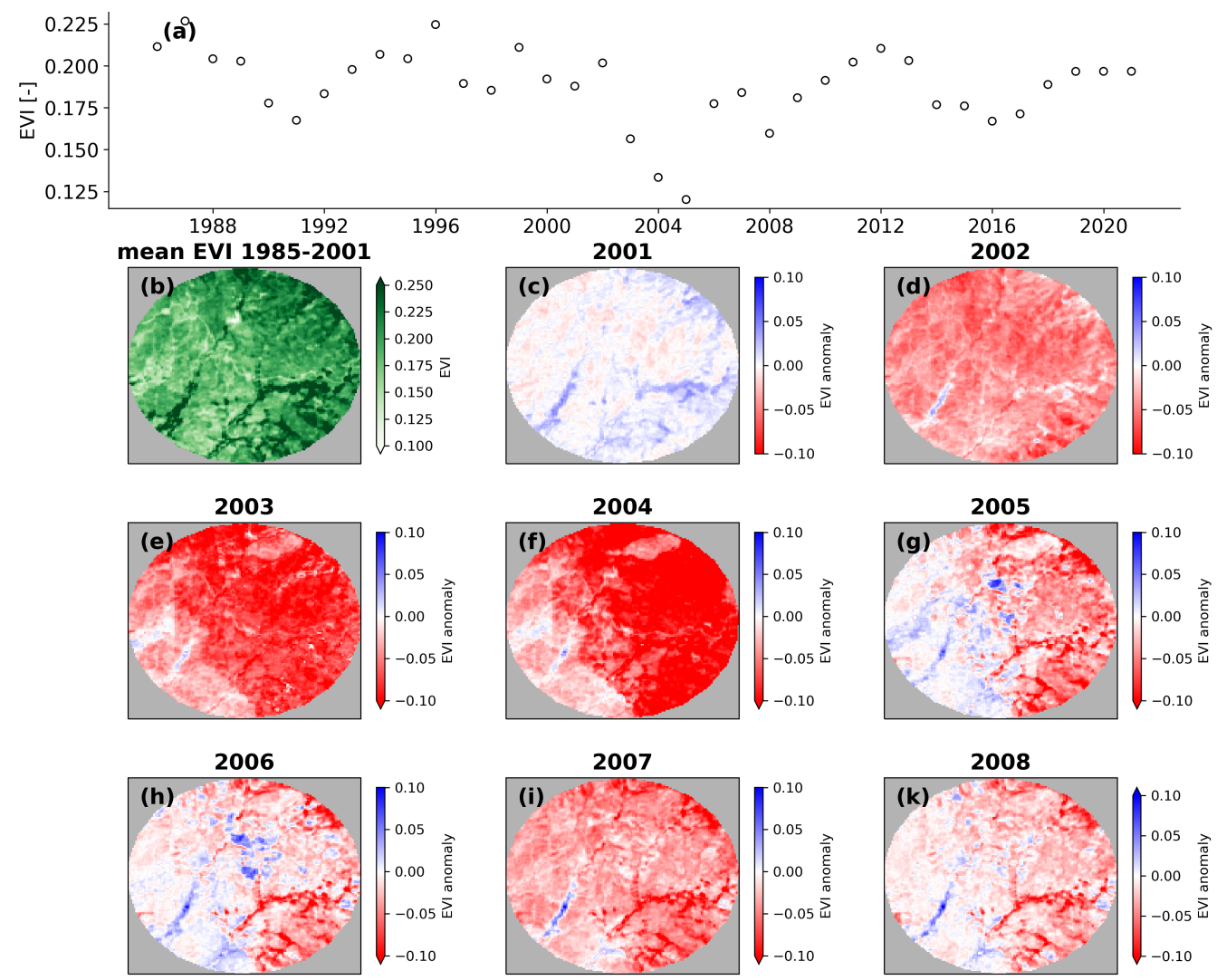

2009

2010
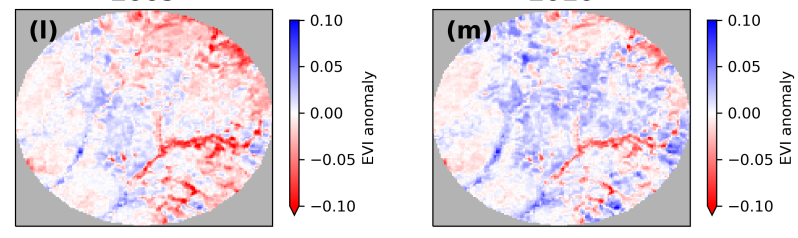

2011

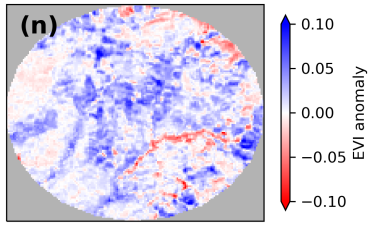

Figure 7. Annual EVI dynamics at the site US-SO3 as observed by Landsat. Time series of spatial average annual EVI for the full $2 \times 2 \mathrm{~km}^{2}$ cutout (a) and the long-term temporal average spatial patterns of EVI (b). Annual anomalies of EVI for the period 2003-2011 in panels c-n (anomaly $\mathrm{EVI}_{\text {year } \mathrm{n}}=\mathrm{EVI}_{\text {year } \mathrm{n}}-$ mean $\left(\mathrm{EVI}_{1985-2001}\right)$. 
https://doi.org/10.5194/bg-2021-314

Preprint. Discussion started: 25 November 2021

(c) Author(s) 2021. CC BY 4.0 License.

(c) (i)

\section{Conclusions}

The proposed methods aim at assuring good quality and producing as reliable as possible gap-free estimates of EO-derived surface reflectance, vegetation indices, and LST for pixels around EC sites. Depending on the question/ application at hand, MODIS or Landsat EO data with their inherently very diverse spatial and temporal resolutions might be more suitable. The requirements for the strictness of the quality checks and the sophistication of the gap-filling methods differ by use case. No approach can fit all requirements, but we expect FluxnetEO to offer many opportunities to advance our understanding of landatmosphere fluxes for individual sites, across regional networks and globally. It helps bridging the Fluxnet, remote sensing, and modelling communities, and facilitates consistent benchmarking of EO-based flux models of any kind. We anticipate that this will accelerate our ability to monitor and understand land-atmosphere fluxes across spatial and temporal scales. For the future we plan to maintain, update and improve FluxnetEO. This will include extending the time series to most recent years, adding EC sites as measurements become available in one of the networks, improving the processing based on newly identified drawbacks and/ or user needs (e.g., Landsat sensors harmonisation), and updating to new EO data collections (e.g. Landsat collection 2). Importantly, forthcoming FluxnetEO versions shall more strongly facilitate complementary usage of multiple missions to exploit their synergy potential, so that future additions will include further EO products, for example the Sentinel missions. Although temporal overlap with most of the EC records is low, it will grow with the lifetime of the different Sentinels and because strong efforts in the EC community target the timely, free and open distribution of site-level measurements.

Data availability. Data sets are available for open and free usage under ICOS Carbon Portal in separate collections Landsat (Walther et al., 2021a, https://meta.icos-cp.eu/collections/-x7_Z4PGRuav5QzwgEY_DErM) and for MODIS (Walther et al., 2021b, https://meta.icos-cp. eu/collections/tEAkpU6UduMMONrFyym5-tUW). Zipped folders package the data by continents and groups of countries. In the zipdirectories, the files are organised by site and in two processing versions: One version contains spatially explicit data fields for each subpixel in the cutout of $2 \times 2 \mathrm{~km}^{2}$ and is denoted by 'subpixel' in the file name. A second version is an average time series per site that represents the area within $1 \mathrm{~km}$ radius of the site with the inverse distance to the tower as weight ('average_cutout'). In this version, at every time step all valid subpixels closer than $1 \mathrm{~km}$ to the site are averaged after the quality checks, and the gap-filling procedure takes this average time series as input. The data fields contained in both processing versions are listed in table 2. Each data field has a complementary data layer with a flag ('gapfilltype') indicating which data point is of original good quality or how a given point has been imputed in the gap-filling procedure. The processing version 'average_cutout' has additional fields that indicate how many valid pixels within $1 \mathrm{~km}$ of the tower contributed to the spatial average per time step ('N') and the spatial standard deviation of the vegetation index or LST for the given time step ('NSTD'). 
https://doi.org/10.5194/bg-2021-314

Preprint. Discussion started: 25 November 2021

(C) Author(s) 2021. CC BY 4.0 License.

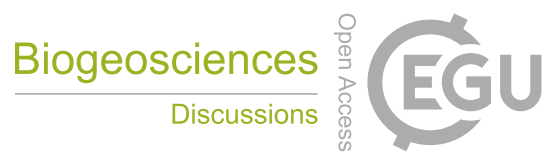

Appendix A: Site selection 
https://doi.org/10.5194/bg-2021-314

Preprint. Discussion started: 25 November 2021

(c) Author(s) 2021. CC BY 4.0 License.

(c) (i)

Table A1. Sites in FluxnetEO: site codes and coordinates (latitude in degree N, longitude in degree E, rounded to 4 decimals). Site codes including $\mathrm{a} *$ indicate sites for which currently only MODIS data are provided.

\begin{tabular}{|c|c|c|c|}
\hline site code & latitude, longitude & site code & latitude, longitude \\
\hline AR-SLu & $-33.4648,-66.4598$ & AR-Vir & $-28.2395,-56.1886$ \\
\hline AT-Neu & $47.1167,11.3175$ & AU-ASM & $-22.283,133.249$ \\
\hline AU-Ade & $-13.0769,131.1178$ & AU-Cpr & $-34.0021,140.5891$ \\
\hline AU-Cum & $-33.6152,150.7236$ & AU-DaP & $-14.0633,131.3181$ \\
\hline AU-DaS & $-14.1593,131.3881$ & AU-Dry & $-15.2588,132.3706$ \\
\hline AU-Emr & $-23.8587,148.4746$ & AU-Fog & $-12.5452,131.3072$ \\
\hline AU-Gin & $-31.3764,115.7138$ & AU-How & $-12.4943,131.1523$ \\
\hline AU-RDF & $-14.5636,132.4776$ & AU-Rob & $-17.1175,145.6301$ \\
\hline AU-TTE & $-22.287,133.64$ & AU-Tum & $-35.6566,148.1517$ \\
\hline AU-Wac & $-37.4259,145.1878$ & AU-Whr & $-36.6732,145.0294$ \\
\hline AU-Wom & $-37.4222,144.0944$ & AU-Ync & $-34.9883,146.2916$ \\
\hline BE-Bra & $51.3076,4.5198$ & BE-Lon & $50.5516,4.7462$ \\
\hline BE-Vie & $50.3049,5.9981$ & BR-Ban & $-9.8244,-50.1591$ \\
\hline BR-Cax & $-1.7197,-51.459$ & BR-Ji2 & $-10.0832,-61.9309$ \\
\hline BR-Sa1 & $-2.8567,-54.9589$ & BR-Sa2 & $-3.0119,-54.5365$ \\
\hline $\mathrm{BR}-\mathrm{Sa} 3$ & $-3.018,-54.9714$ & BR-Sp1 & $-21.6195,-47.6499$ \\
\hline BW-Ma1 & $-19.9165,23.5603$ & CA-Ca1 & $49.8673,-125.3336$ \\
\hline $\mathrm{CA}-\mathrm{Ca} 2$ & $49.8705,-125.2909$ & $\mathrm{CA}-\mathrm{Ca} 3$ & $49.5346,-124.9004$ \\
\hline CA-Gro & $48.2167,-82.1556$ & CA-Let & $49.7093,-112.9402$ \\
\hline CA-Man & $55.8796,-98.4808$ & CA-Mer & $45.4094,-75.5186$ \\
\hline CA-NS1 & $55.8792,-98.4839$ & CA-NS2 & $55.9058,-98.5247$ \\
\hline CA-NS3 & $55.9117,-98.3822$ & CA-NS4 & $55.9144,-98.3806$ \\
\hline CA-NS5 & $55.8631,-98.485$ & CA-NS6 & 55.9167, -98.9644 \\
\hline CA-NS7 & $56.6358,-99.9483$ & CA-Oas & $53.6289,-106.1978$ \\
\hline $\mathrm{CA}-\mathrm{Obs}$ & $53.9872,-105.1178$ & CA-Ojp & $53.9163,-104.692$ \\
\hline CA-Qcu & $49.2671,-74.0365$ & CA-Qfo & $49.6925,-74.3421$ \\
\hline CA-SF1 & $54.485,-105.8176$ & CA-SF2 & $54.2539,-105.8775$ \\
\hline CA-SF3 & $54.0916,-106.0053$ & CA-SJ1 & $53.908,-104.656$ \\
\hline $\mathrm{CA}-\mathrm{SJ} 2$ & $53.945,-104.649$ & CA-SJ3 & $53.8758,-104.6453$ \\
\hline CA-TP1 & $42.6609,-80.5595$ & CA-TP2 & $42.7744,-80.4588$ \\
\hline CA-TP3 & $42.7068,-80.3483$ & CA-TP4 & $42.7102,-80.3574$ \\
\hline CA-TPD & $42.6353,-80.5577$ & CA-WP1 & $54.9538,-112.467$ \\
\hline CA-WP3 & $54.47,-113.32$ & CG-Tch & $-4.2892,11.6564$ \\
\hline $\mathrm{CH}-\mathrm{Aws}$ & $46.5832,9.7904$ & CH-Cha & $47.2102,8.4104$ \\
\hline CH-Dav & $46.8153,9.8559$ & $\mathrm{CH}-\mathrm{Fru}$ & $47.1158,8.5378$ \\
\hline
\end{tabular}


https://doi.org/10.5194/bg-2021-314

Preprint. Discussion started: 25 November 2021

(c) Author(s) 2021. CC BY 4.0 License.

\begin{tabular}{|c|c|c|c|}
\hline site code & latitude, longitude & site code & latitude, longitude \\
\hline CH-Lae & $47.4781,8.365$ & $\mathrm{CH}-\mathrm{Oe} 1$ & $47.2858,7.7319$ \\
\hline $\mathrm{CH}-\mathrm{Oe} 2$ & $47.2863,7.7343$ & CN-Anh & $33.0,117.0$ \\
\hline CN-Bed & $39.5306,116.252$ & CN-Cha & $42.4025,128.0958$ \\
\hline CN-Cng & $44.5934,123.5092$ & CN-Dan & $30.4978,91.0664$ \\
\hline CN-Din & $23.1733,112.5361$ & CN-Do1 & $31.5167,121.961$ \\
\hline CN-Do2 & $31.5847,121.903$ & CN-Do3 & $31.5169,121.972$ \\
\hline CN-Du1 & $42.0456,116.671$ & CN-Du2 & $42.0467,116.2836$ \\
\hline CN-Du3 & $42.0551,116.2809$ & CN-HaM & $37.37,101.18$ \\
\hline CN-Hny & $29.31,112.51$ & $\mathrm{CN}-\mathrm{Ku} 1$ & $40.5383,108.694$ \\
\hline $\mathrm{CN}-\mathrm{Ku} 2$ & $40.3808,108.549$ & CN-Qia & $26.734,115.0663$ \\
\hline $\mathrm{CN}-\mathrm{Sw} 2$ & $41.7902,111.8971$ & $\mathrm{CN}-\mathrm{Xi1}$ & $43.5458,116.6778$ \\
\hline CZ-BK1 & $49.5021,18.5369$ & $\mathrm{CZ}-\mathrm{BK} 2 *$ & $49.4944,18.5428$ \\
\hline CZ-Lnz & $48.6816,16.9464$ & CZ-RAJ & $49.4437,16.6965$ \\
\hline CZ-Stn & $49.036,17.9699$ & CZ-wet & $49.0246,14.7704$ \\
\hline DE-Akm & $53.8662,13.6834$ & DE-Bay & $50.1419,11.8669$ \\
\hline DE-Geb & $51.0997,10.9146$ & DE-Gri & $50.95,13.5126$ \\
\hline DE-Hai & $51.0792,10.453$ & DE-Har & $47.9344,7.601$ \\
\hline DE-HoH & $52.0853,11.2192$ & DE-Hte & $54.2103,12.1761$ \\
\hline DE-Hzd & $50.9638,13.4898$ & DE-Kli & $50.8931,13.5224$ \\
\hline DE-Lkb & $49.0996,13.3047$ & DE-Lnf & $51.3282,10.3678$ \\
\hline DE-Meh & $51.2753,10.6555$ & DE-Obe & $50.7867,13.7213$ \\
\hline DE-RuR & $50.6219,6.3041$ & DE-RuS & $50.8659,6.4471$ \\
\hline DE-RuW & $50.5049,6.331$ & DE-Seh & $50.8706,6.4497$ \\
\hline DE-SfN & $47.8064,11.3275$ & DE-Spw & $51.8922,14.0337$ \\
\hline DE-Tha & $50.9626,13.5652$ & DE-Wet & $50.4535,11.4575$ \\
\hline DE-Zrk & $53.8759,12.889$ & DK-Eng & $55.6905,12.1918$ \\
\hline DK-Fou & $56.4842,9.5872$ & DK-Lva & $55.6833,12.0833$ \\
\hline DK-Ris & $55.5303,12.0972$ & DK-Sor & $55.4859,11.6446$ \\
\hline ES-Abr & $38.7018,-6.7859$ & ES-Amo & $36.8336,-2.2523$ \\
\hline ES-ES1 & $39.346,-0.3188$ & ES-ES2 & $39.2756,-0.3153$ \\
\hline ES-LJu & $36.9266,-2.7521$ & ES-LM1 & $39.9427,-5.7787$ \\
\hline ES-LM2 & $39.9346,-5.7759$ & ES-LMa & $39.9415,-5.7734$ \\
\hline ES-LgS & $37.0979,-2.9658$ & ES-Ln2 & $36.9695,-3.4758$ \\
\hline ES-VDA & $42.1522,1.4485$ & FI-Hyy & $61.8474,24.2948$ \\
\hline FI-Jok & $60.8986,23.5134$ & FI-Kaa & $69.1406,27.2698$ \\
\hline FI-Let & $60.6418,23.9595$ & FI-Lom & $67.9972,24.2092$ \\
\hline
\end{tabular}


https://doi.org/10.5194/bg-2021-314

Preprint. Discussion started: 25 November 2021

(c) Author(s) 2021. CC BY 4.0 License.

\begin{tabular}{|c|c|c|c|}
\hline site code & latitude, longitude & site code & latitude, longitude \\
\hline FI-Sii & $61.8326,24.1928$ & FI-Sod & $67.3624,26.6386$ \\
\hline FI-Var & $67.7549,29.61$ & FR-Aur & $43.5497,1.1061$ \\
\hline FR-Bil & $44.4937,-0.9561$ & FR-EM2 & $49.8721,3.0206$ \\
\hline FR-Fon & $48.4764,2.7801$ & FR-Gri & $48.8442,1.9519$ \\
\hline FR-Hes & $48.6741,7.0646$ & FR-LBr & $44.7171,-0.7693$ \\
\hline FR-Lam & $43.4965,1.2378$ & FR-Lq1 & $45.6431,2.7358$ \\
\hline FR-Lq2 & $45.6392,2.737$ & FR-Pue & $43.7413,3.5957$ \\
\hline GF-Guy & $5.2788,-52.9249$ & GH-Ank & $5.2685,-2.6942$ \\
\hline GL-NuF* & $64.1308,-51.3861$ & GL-ZaF & $74.4814,-20.5545$ \\
\hline GL-ZaH & $74.4733,-20.5503$ & HU-Bug & $46.6911,19.6013$ \\
\hline HU-Mat & $47.8469,19.726$ & ID-Pag & $2.345,114.036$ \\
\hline IE-Ca1 & $52.8588,-6.9181$ & IE-Dri & $51.9867,-8.7518$ \\
\hline IL-Yat* & $31.345,35.052$ & IS-Gun & $63.8333,-20.2167$ \\
\hline IT-Amp & $41.9041,13.6052$ & IT-BCi & $40.5238,14.9574$ \\
\hline IT-Bon & $39.4778,16.5347$ & IT-CA1 & $42.3804,12.0266$ \\
\hline IT-CA2 & $42.3772,12.026$ & IT-CA3 & $42.38,12.0222$ \\
\hline IT-Col & $41.8494,13.5881$ & IT-Cp2 & $41.7043,12.3573$ \\
\hline IT-Cpz & $41.7052,12.3761$ & IT-Isp & $45.8126,8.6336$ \\
\hline IT-LMa & $45.1526,7.5826$ & IT-La2 & $45.9542,11.2853$ \\
\hline IT-Lav & $45.9562,11.2813$ & IT-Lec & $43.3036,11.2698$ \\
\hline IT-Lsn & $45.7405,12.7503$ & IT-MBo & $46.0147,11.0458$ \\
\hline IT-Mal & $46.114,11.7033$ & IT-Noe & $40.6062,8.1512$ \\
\hline IT-Non & $44.6902,11.0911$ & IT-PT1 & $45.2009,9.061$ \\
\hline IT-Pia & $42.5839,10.0784$ & IT-Ren & $46.5869,11.4337$ \\
\hline IT-Ro1 & $42.4081,11.93$ & IT-Ro2 & $42.3903,11.9209$ \\
\hline IT-SR2 & $43.732,10.291$ & IT-SRo & $43.7279,10.2844$ \\
\hline IT-Tor & $45.8444,7.5781$ & JP-MBF & $44.3842,142.3186$ \\
\hline JP-Mas & $36.054,140.0269$ & JP-SMF & $35.2617,137.0786$ \\
\hline JP-Tak & $36.1462,137.423$ & JP-Tom & $42.7395,141.5149$ \\
\hline MY-PSO & $2.973,102.3062$ & NL-Ca1 & $51.971,4.927$ \\
\hline NL-Haa & $52.0036,4.8056$ & NL-Hor & $52.2404,5.0713$ \\
\hline NL-Lan & $51.9536,4.9029$ & NL-Loo & $52.1666,5.7436$ \\
\hline NL-Lut & $53.3989,6.356$ & PA-SPn & $9.3181,-79.6346$ \\
\hline PA-SPs & $9.3138,-79.6314$ & PL-Wet & $52.7622,16.3094$ \\
\hline PT-Esp & $38.6394,-8.6018$ & PT-Mi1 & $38.5406,-8.0001$ \\
\hline PT-Mi2 & $38.4765,-8.0246$ & RU-Che & $68.613,161.3414$ \\
\hline RU-Cok & $70.8291,147.4943$ & RU-Fy2 & $56.4476,32.9019$ \\
\hline
\end{tabular}


https://doi.org/10.5194/bg-2021-314

Preprint. Discussion started: 25 November 2021

(c) Author(s) 2021. CC BY 4.0 License.

\begin{tabular}{|c|c|c|c|}
\hline site code & latitude, longitude & site code & latitude, longitude \\
\hline RU-Fyo & $56.4615,32.9221$ & RU-Ha1 & $54.7252,90.0022$ \\
\hline RU-Ha3 & $54.7046,89.0778$ & RU-Sam & $72.3738,126.4958$ \\
\hline RU-SkP & $62.255,129.168$ & RU-Tks & $71.5943,128.8878$ \\
\hline RU-Vrk & $67.0547,62.9405$ & RU-Zot & $60.8008,89.3508$ \\
\hline SD-Dem & $13.2829,30.4783$ & SE-Abi & $68.3624,18.7948$ \\
\hline SE-Deg & $64.182,19.5565$ & SE-Htm & $56.0976,13.419$ \\
\hline SE-Lnn* & $58.3406,13.1018$ & SE-Nor & $60.0865,17.4795$ \\
\hline SE-Ros* & $64.1725,19.738$ & SE-Sk2 & $60.1297,17.8401$ \\
\hline SE-St1 & $68.3541,19.0503$ & SE-Svb* & $64.2561,19.7745$ \\
\hline SJ-Adv & $78.186,15.923$ & SJ-Blv & $78.9216,11.8311$ \\
\hline SK-Tat & $49.1208,20.1635$ & SN-Dhr & $15.4028,-15.4322$ \\
\hline UK-ESa & $55.9069,-2.8586$ & UK-Gri & $56.6072,-3.7981$ \\
\hline UK-Ham & $51.1535,-0.8583$ & UK-PL3 & $51.45,-1.2667$ \\
\hline UK-Tad & $51.2071,-2.8286$ & US-AR1 & $36.4267,-99.42$ \\
\hline US-AR2 & $36.6358,-99.5975$ & US-ARM & $36.6058,-97.4888$ \\
\hline US-ARb & $35.5497,-98.0402$ & US-ARc & $35.5465,-98.04$ \\
\hline US-Atq & $70.4696,-157.4089$ & US-Aud & $31.5907,-110.5104$ \\
\hline US-Bar & $44.0646,-71.2881$ & US-Bkg & $44.3453,-96.8362$ \\
\hline US-Blo & $38.8953,-120.6328$ & US-Bn2 & $63.9198,-145.3782$ \\
\hline US-Bn3 & $63.9227,-145.7442$ & US-Bo1 & $40.0062,-88.2904$ \\
\hline US-Bo2 & $40.009,-88.29$ & US-Brw & $71.3225,-156.6092$ \\
\hline US-CRT & $41.6285,-83.3471$ & US-CaV & $39.0633,-79.4208$ \\
\hline US-Cop & $38.09,-109.39$ & US-Dk3 & $35.9782,-79.0942$ \\
\hline US-FPe & $48.3077,-105.1019$ & US-FR2 & $29.9495,-97.9962$ \\
\hline US-Fmf & $35.1426,-111.7273$ & US-Fuf & $35.089,-111.762$ \\
\hline US-Fwf & $35.4454,-111.7718$ & US-GBT & $41.3658,-106.2397$ \\
\hline US-GLE & $41.3665,-106.2399$ & US-Goo & $34.2547,-89.8735$ \\
\hline US-Ha1 & $42.5378,-72.1715$ & US-Ho1 & $45.2041,-68.7402$ \\
\hline US-Ho2 & $45.2091,-68.747$ & US-IB1 & $41.8593,-88.2227$ \\
\hline US-IB2 & $41.8406,-88.241$ & US-Ivo & $68.4865,-155.7503$ \\
\hline US-KS1 & $28.4583,-80.6709$ & US-KS2 & $28.6086,-80.6715$ \\
\hline US-LWW & $34.9604,-97.9789$ & US-Lin & $36.3566,-119.8423$ \\
\hline US-Los & $46.0827,-89.9792$ & US-MMS & $39.3232,-86.4131$ \\
\hline US-MOz & $38.7441,-92.2$ & US-Me1 & $44.5794,-121.5$ \\
\hline US-Me2 & $44.4523,-121.5574$ & US-Me3 & $44.3154,-121.6078$ \\
\hline US-Me4 & $44.4992,-121.6224$ & US-Me5 & $44.4372,-121.5668$ \\
\hline
\end{tabular}


https://doi.org/10.5194/bg-2021-314

Preprint. Discussion started: 25 November 2021

(c) Author(s) 2021. CC BY 4.0 License.

\begin{tabular}{|c|c|c|c|}
\hline site code & latitude, longitude & site code & latitude, longitude \\
\hline US-Me6 & $44.3233,-121.6078$ & US-Myb & $38.0498,-121.7651$ \\
\hline US-NC1 & $35.8118,-76.7119$ & US-NR1 & $40.0329,-105.5464$ \\
\hline US-Ne1 & $41.1651,-96.4766$ & US-Ne2 & $41.1649,-96.4701$ \\
\hline US-Ne3 & 41.1797, -96.4397 & US-ORv & $40.0201,-83.0183$ \\
\hline US-Oho & $41.5545,-83.8438$ & US-PFa & $45.9459,-90.2723$ \\
\hline US-Prr & $65.1237,-147.4876$ & US-SO2 & $33.3738,-116.6228$ \\
\hline US-SO3 & $33.3771,-116.6226$ & US-SO4 & $33.3845,-116.6406$ \\
\hline US-SP1 & $29.7381,-82.2188$ & US-SP2 & $29.7648,-82.2448$ \\
\hline US-SP3 & $29.7548,-82.1633$ & US-SRC & $31.9083,-110.8395$ \\
\hline US-SRG & $31.7894,-110.8277$ & US-SRM & $31.8214,-110.8661$ \\
\hline US-Sta & $41.3966,-106.8024$ & US-Syv & $46.242,-89.3477$ \\
\hline US-Ton & $38.4316,-120.966$ & US-Tw1 & $38.1074,-121.6469$ \\
\hline US-Tw2 & $38.1047,-121.6433$ & US-Tw3 & $38.1159,-121.6467$ \\
\hline US-Tw4 & $38.103,-121.6414$ & US-Twt & $38.1087,-121.653$ \\
\hline US-UMB & $45.5598,-84.7138$ & US-UMd & $45.5625,-84.6975$ \\
\hline US-Var & $38.4133,-120.9507$ & US-WBW & $35.9588,-84.2874$ \\
\hline US-WCr & $45.8059,-90.0799$ & US-WPT & $41.4646,-82.9962$ \\
\hline US-Whs & $31.7438,-110.0522$ & US-Wi0 & $46.6188,-91.0814$ \\
\hline US-Wi1 & $46.7305,-91.2329$ & US-Wi2 & $46.6869,-91.1528$ \\
\hline US-Wi3 & $46.6347,-91.0987$ & US-Wi4 & $46.7393,-91.1663$ \\
\hline US-Wi5 & $46.6531,-91.0858$ & US-Wi6 & $46.6249,-91.2982$ \\
\hline US-Wi7 & $46.6491,-91.0693$ & US-Wi8 & $46.7223,-91.2524$ \\
\hline US-Wi9 & $46.6188,-91.0814$ & US-Wkg & $31.7365,-109.9419$ \\
\hline US-Wrc & $45.8205,-121.9519$ & VU-Coc & $-15.4427,167.192$ \\
\hline ZA-Kru & $-25.0197,31.4969$ & ZM-Mon & $-15.4378,23.2528$ \\
\hline
\end{tabular}


https://doi.org/10.5194/bg-2021-314

Preprint. Discussion started: 25 November 2021

(c) Author(s) 2021. CC BY 4.0 License.

(c) (i)

\section{Appendix B: Technical details about the processing of surface reflectance}

In this section we provide all specific technical details necessary to reproduce our processing steps for the surface reflectance of MODIS and Landsat.

The quality control of the MODIS reflectance-based land surface indicators included the following steps:

- Omission of the MCD43A2 BRDF_Albedo_Band_Quality_BandX flags $\geq 3$ for each band to remove bad inversion quality from the surface reflectances.

- The flag Snow_BRDF_Albedo eliminated pixels that contain snow. As the gap-filling procedure used the snow information, a spatially aggregated snow flag was needed for the processing version that averages valid data within $1 \mathrm{~km}$ of the tower. For this, we defined the aggregated snow flag as the fraction of subpixels in the cutout that are snow covered. If more than $50 \%$ of subpixels have missing snow information for a certain day, the aggregated snow flag is set to missing as well.

- The presence of water in a scene seen by an optical sensor can strongly affect the observation. The BRDF_Albedo_LandWaterType flag allowed to filter for pixels exclusively on land (flag=1). This eliminated all data for many Swiss, Dutch, Italian and Finnish sites which are situated close to water bodies. Inclusion of ocean coastlines and lake shorelines (flag=2) and shallow inland water (flag=3) resulted in reasonable time series at most sites. This came at the cost of having few other sites that were affected by the presence of water. As a trade-off between data availability and quality, we decided to include land-water flags 1-3.

- After the computation of the vegetation indices from the individual spectral bands, an additional check removed possible values of the spectral vegetation indices outside their defined ranges. An outlier filter compared each value to the median of all valid values in temporal windows of 30 days (Papale et al., 2006). A large difference of a given value to the median of its surrounding values indicates a potential outlier. The threshold $\mathrm{z}$ as in Papale et al. (2006) was set to 2, and only a less conservative threshold of $\mathrm{z}=3$ acted when more than 20 valid values were available in a given window.

The empirical outlier filter for Landsat slightly differed from the one for MODIS and removed observations in the five highest and lowest percentiles of the mean seasonal cycle of an index if they differed more than $75 \%$ from their surrounding 3-months moving window median. The second criterion was critical in order to preserve observations of disturbance events or recovery dynamics.

Technical details for the gap-filling:

1. The first step is a moving window median to fill short non-snow related gaps. If the entire time series has less than $40 \%$ valid data, a given moving window contains both the actual values and the median seasonal cycle for the given time of the year. The median for the moving window refers then to the distribution of both. 
https://doi.org/10.5194/bg-2021-314

Preprint. Discussion started: 25 November 2021

(c) Author(s) 2021. CC BY 4.0 License.

(c) (i)

2. The second step fills reflectance values with a constant value in the presence of snow ( $\operatorname{snow}$ flag $\geq 0.1$ ). Partly long periods with missing snow information in the Snow_BRDF_Albedo flag needed special treatment. Some of these gaps appeared systematically in early winter in higher latitudes, so also times of missing snow information are considered as snow covered. However, also during the growing season long periods of missing snow information occur in several sites globally. The following criteria check whether a period that is considered snow covered by high values or missing snow flags is filled with a constant baseline value or not:

- If a given site has less than 60 days with valid snow coverage (i.e. Snow_BRDF_Albedo=1) in the total record, snow typically does not occur at the site. In this case the gap-filling procedure does not apply this gap-filling step at all for this site.

- The gap-filling with a constant value only addresses gaps with a minimum length of 20 consecutive days with snow flag missing or 1 . This avoids filling very short intermittent snow periods or short gaps in snow information during the growing season.

- This gap-filling step does not consider gaps due to missing snow information if the median seasonal cycle of snow coverage indicates $\leq 5 \%$ of snow cover at the given time of the year and the difference between the fill value and the median seasonal cycle is large (i.e. exceeds the $85^{\text {th }}$ percentile of the differences in times of missing snow information).

The constant baseline value that is used to fill snow periods in the time series for a site represents the $3^{\text {rd }}$ percentile of the median seasonal cycle of the spectral vegetation indices. If a given index typically has high values outside the growing season, the baseline value represents the $97^{\text {th }}$ percentile instead. However, if for a given winter the average over the last 5 valid data points at the end of the growing season or over the first 5 valid data points at the beginning of the next growing season is lower than the baseline value (higher than the baseline for indices which are typically high outside the growing season), the baseline takes the value of this average for the given winter (similar to Beck et al., 2007).

3. Linearly scale the median seasonal cycle to the time series to fill longer gaps (Verger et al., 2013). Calibration happens in moving temporal windows of 80 days, and application of the scaling in steps of 20 days.

\section{Appendix C: Technical details about the processing of MODIS LST}

In this section we provide all specific technical details necessary to reproduce the processing steps for the MODIS LST.

The empirical filter to remove potential outlier values (Papale et al., 2006) followed the same procedure like for the vegetation indices, but used a constant z-value of 1.5 as it provided the best trade-off between filter success, wrong positives and wrong negatives.

Estimates of LST in data gaps originate from the following steps: 
https://doi.org/10.5194/bg-2021-314

Preprint. Discussion started: 25 November 2021

(c) Author(s) 2021. CC BY 4.0 License.

(c) (i)

Discussions

- In contrast to the procedure for the reflectance-based vegetation indices, the distribution of values in the temporal windows of 8 days is not supplied by the median seasonal cycle in case of low data availability. The moving window median was not applied for windows with less than three valid values.

- Filling by linearly scaling the median seasonal shift between any two of the four MODIS LST time series to each other (Crosson et al., 2012; Li et al., 2018). The following explains this gap-filling step for TERRA $A_{\text {day }}$ as the 'imputed' time series:

1. Obtain the median seasonal cycle (MSC) of the shift between TERRA day and AQUA day: $\operatorname{MSC}\left(\Delta\left(\right.\right.$ TERRA $\left.\left._{\text {day }}, \mathrm{AQUA}_{\text {day }}\right)\right)$.

2. Linearly scale MSC( $\left.\Delta{\left(\text { TERRA }_{\text {day }}, A Q U A_{d a y}\right)}\right)$ to $\Delta\left(\right.$ TERRA $_{\text {day }}, A_{Q U A}$ day $)$ in temporal windows of 80 days (provided a minimum of 10 valid values in a given window). Apply the scaling in windows and steps of 20 days.

$\Delta\left(\text { TERRA }_{\text {day }}, \operatorname{AQUA}_{\text {day }}\right)_{t=k: k+80}=\mathrm{f}\left(\operatorname{MSC}\left(\Delta\left(\text { TERRA }_{\text {day }}, \operatorname{AQUA}_{\text {day }}\right)\right)_{\mathrm{t}=\mathrm{k}: k+80}\right)$

$\Delta\left(\right.$ TERRA $\left.\left._{\text {day }}, \operatorname{AQUA}_{\text {day }}\right)\right)^{*} t=k: k+20=m \cdot \operatorname{MSC}\left(\Delta\left(\text { TERRA }_{\text {day }}, \operatorname{AQUA}_{\text {day }}\right)\right)_{\mathrm{t}=\mathrm{k}: \mathrm{k}+20}+\mathrm{n}$.

3. Add the scaled average shift to the $A Q U A_{\text {day }}$ to obtain an estimate of TERRA day $*\left[A Q U A_{\text {day }}\right]$.

TERRA $\left.\left._{\text {day }}{ }_{\mathrm{t}=\mathrm{k}: \mathrm{k}+20}[] \mathrm{AQUA} \mathrm{A}_{\text {day }}\right]=\mathrm{AQUA}_{\text {day } t=k: k+20}+\Delta\left(\mathrm{TERRA}_{\text {day }}, \mathrm{AQUA}_{\text {day }}\right)\right)_{\mathrm{t}=\mathrm{k}: \mathrm{k}+20}$

Analogously to TERRA $A_{\text {day }} *\left[A Q U A_{\text {day }}\right]$, also the night-time LST observations contributed to estimate TERRA $_{\text {day }} *\left[\right.$ TERRA $\left._{\text {night }}\right]$ and TERRA $A_{\text {day }} *\left[\mathrm{AQUA}_{\text {night }}\right]$. All three estimates TERRA day $*\left[\mathrm{AQUA}_{\text {day }}\right], \mathrm{TERRA}_{\text {day }} *\left[\mathrm{TERRA}_{\text {night }}\right]$ and TERRA $\mathrm{Tay}_{\text {da }} *\left[\mathrm{AQUA} \mathrm{A}_{\text {night }}\right]$, served to fill gaps in TERRA $A_{\text {day }}$, namely in the order of increasing standard deviation of the differences between valid TERRA $_{\text {day }}$ and each of the three estimated TERRA day $*$

The procedure analogously filled $A Q U A_{\text {day }}$, TERRA $_{\text {night }}$ and AQUA $A_{\text {night }}$ accordingly using valid observations of the remaining three, respectively.

- Linearly scale the MSC of one LST time series to the actual time series in temporal windows. As in step 2, the calibration happened in temporal windows of 80 days, while the scaling was applied in windows of 20 days. Exemplarily for TERRA $_{\text {day }}:$ TERRA $_{\text {day } t=k: k+80}=f\left(\operatorname{MSC}\left(\text { TERRA }_{\text {day }}\right)_{t=k: k+80}\right)$

TERRA $_{\text {day }}{ }_{\mathrm{t}=\mathrm{k}: \mathrm{k}+20}=\mathrm{m} \cdot \operatorname{MSC}\left(\text { TERRA }_{\text {day }}\right)_{\mathrm{t}=\mathrm{k}: \mathrm{k}+20}+\mathrm{n}$ 
https://doi.org/10.5194/bg-2021-314

Preprint. Discussion started: 25 November 2021

(c) Author(s) 2021. CC BY 4.0 License.

(c) (i)

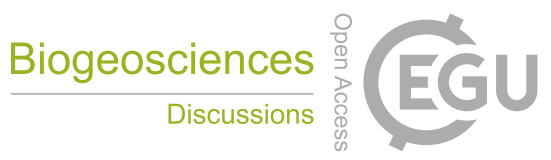

\section{Appendix D: Details about the analysis of spatial context}

For the analysis at DE-Geb and ES-LM1 we used night-time partitioned GPP (Reichstein et al., 2005) with the mean of the variable $u \star$-threshold (GPP_NT_VUT_MEAN) from the Drought 2018 Team and ICOS Ecosystem Thematic Centre (2020) data release (Migliavacca et al., 2020; ICOS Ecosystem Thematic Centre and Gebesee, 2019). We computed the actual flux footprints after Kljun et al. (2015) from ICOS drought 2018 data (Drought 2018 Team and ICOS Ecosystem Thematic Centre, 2020) using the R-code version (V1.41) of the FFP-tool. As a flux footprint for the intersection with EVI we define the area that contributes $80 \%$ to the flux footprint probability density function ( $80 \%$ isoline of the monthly/daily cumulative flux footprint for Landsat and MODIS, respectively).

Flux footprint calculation followed the same procedure for the three measurement heights at RU-Zo2. Surface temperature was inverted from long-wave outgoing radiation measured at a fixed height of $302 \mathrm{~m}$ using Stefan-Boltzmann law. As the inverted surface temperature was compared to LST AQUA ${ }_{\text {day }}$, the average of half-hourly outgoing long-wave radiation for the nominal overpass time at $1.30 \mathrm{pm} \pm 1.5$ hours was taken. Surface emissivity is unknown and we assumed emissivity=1 throughout the year. Only days with good quality in both the LST and the long-wave outgoing radiation are used according to the following criteria: i) more than $90 \%$ of the EO cutout have valid (i.e. non-gapfilled) values which restricts the comparison to clear-sky conditions, and ii) at least $50 \%$ of the half-hourly long-wave fluxes in a given day are of good quality. A larger cutout of $5 \times 5 \mathrm{~km}^{2}$ was extracted for MODIS LST to fully cover also the extent of the flux footprint of the highest measurement level, but is used only for illustrative purposes and not in the data provided in the FluxnetEO collections. 

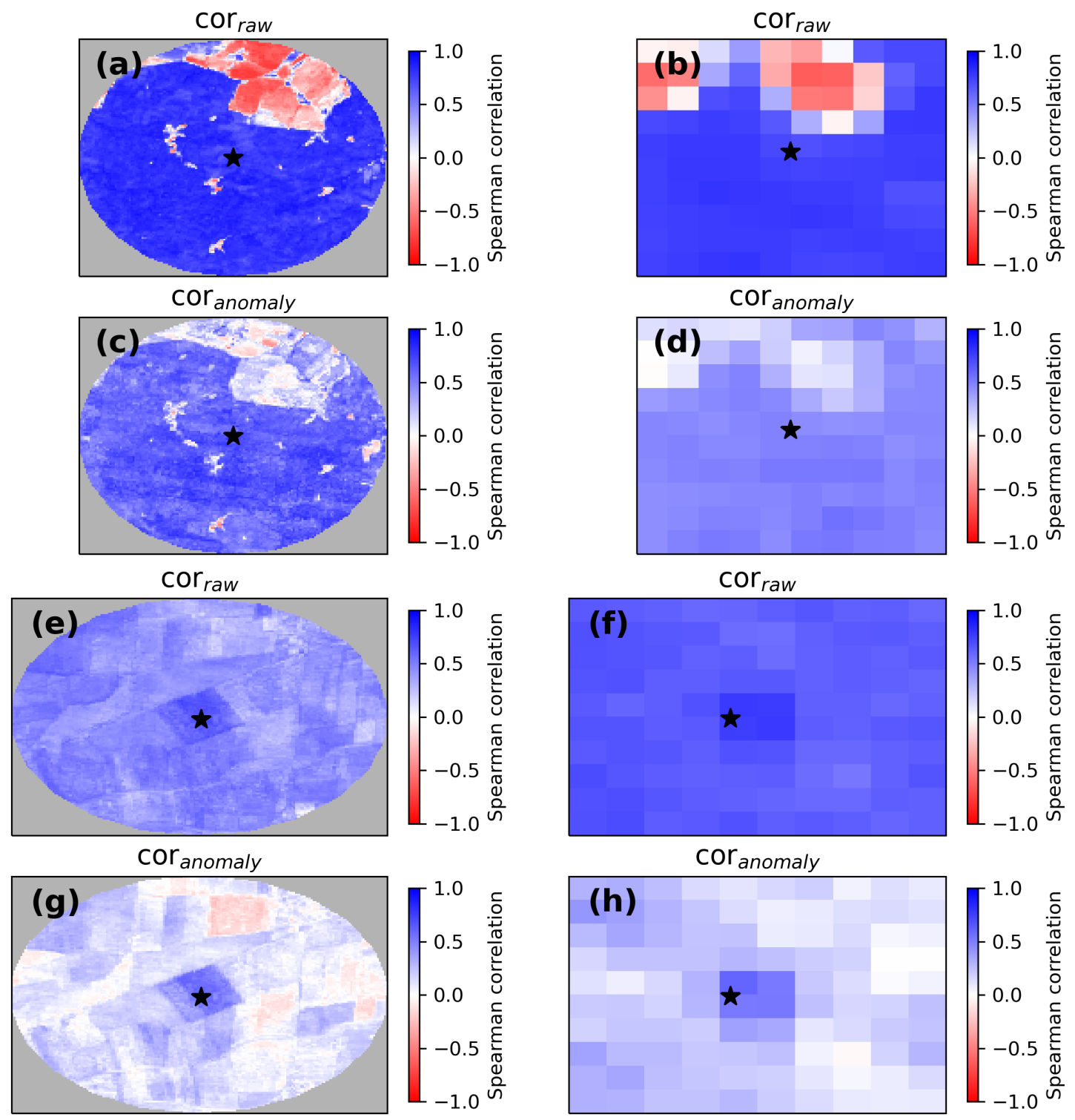

Figure D1. Spearman correlation between EVI and GPP using monthly Landsat (a, c, e, g) and daily MODIS (b, d, f, h) data for ES-LM1 (a-d) and DE-Geb (e-h) Fluxnet sites. The correlation estimates were computed on the raw time series (a, b, e, f) and on the anomalies (c, d, $\mathrm{g}, \mathrm{h})$. 
https://doi.org/10.5194/bg-2021-314

Preprint. Discussion started: 25 November 2021

(c) Author(s) 2021. CC BY 4.0 License.

(c) (1)

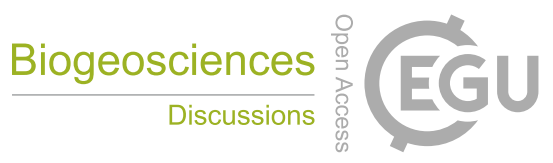

Author contributions. JN and UW compiled the site coordinates and established the pipeline to obtain EO data from Google Earth Engine, and unified formats. SW developed the processing steps for MODIS data with the input from MJ, MM and JN. SB adapted the processing to

485 Landsat data. SE provided model coefficients, code and guidance on its usage for the LST geometrical correction. SW and UW created the files that are offered to the community. TE computed flux footprints for the example sites and analysed them with respect to the satellite data together with SW and SB. SW wrote the manuscript with contributions from all authors, especially MM, SB, TE.

Competing interests. The authors declare no competing interests.

Acknowledgements. We thank the team at the ICOS Carbon Portal for their support in publishing the FluxnetEO data sets, great thanks in particular to Ute Karstens and Zois Zogopoulos.

SW acknowledges funding from an ESA Living Planet Fellowship in the project Vad3e mecum. MJ and JN acknowledge funding from the EU H2020 projects CoCO2 (GA 958927), VERIFY (GA 776810), and E-SHAPE (GA 820852). AVP acknowledges funding from the Max Planck Society (Germany), Russian Foundation for Basic Research, Krasnoyarsk Territory and Krasnoyarsk Regional Fund of Science, project 20-45-242908. FS and CB acknowledge funds from the German Federal Ministry of Food and Agriculture (BMEL) received through the Thünen Institute of Climate-Smart Agriculture. SB acknowledges funding from the European Union through the BIOMASCAT (project code: 4000115192/18/I/NB) (https://eo4society.esa.int/projects/biomascat/) and VERIFY (project code: BO-55-101-006) (https:// cordis.europa.eu/project/id/776810) projects. 
https://doi.org/10.5194/bg-2021-314

Preprint. Discussion started: 25 November 2021

(c) Author(s) 2021. CC BY 4.0 License.

(c) (i)

\section{References}

Badgley, G., Field, C. B., and Berry, J. A.: Canopy near-infrared reflectance and terrestrial photosynthesis, Science Advances, 3, https://doi.org/10.1126/sciadv.1602244, 2017.

Baldocchi, D.: Breathing of the terrestrial biosphere: lessons learned from a global network of carbon dioxide flux measurement systems, Australian Journal of Botany, 56, https://doi.org/10.1071/BT07151, 2008.

Baldocchi, D., Chu, H., and Reichstein, M.: Inter-annual variability of net and gross ecosystem carbon fluxes: A review, Agricultural and Forest Meteorology, 249, 520-533, https://doi.org/https://doi.org/10.1016/j.agrformet.2017.05.015, 2018.

505 Baldocchi, D. D.: How eddy covariance flux measurements have contributed to our understanding of Global Change Biology, Global Change Biology, 26, 242-260, https://doi.org/https://doi.org/10.1111/gcb.14807, 2020.

Beck, P. S. A., Jönsson, P., Høgda, K., Karlsen, S. R., Eklundh, L., and Skidmore, A. K.: A ground-validated NDVI dataset for monitoring vegetation dynamics and mapping phenology in Fennoscandia and the Kola peninsula, International Journal of Remote Sensing, 28, 4311-4330, https://doi.org/10.1080/01431160701241936, 2007.

510 Camps-Valls, G., Campos-Taberner, M., Moreno-Martínez, Á., Walther, S., Duveiller, G., Cescatti, A., Mahecha, M. D., Muñoz-Marí, J., García-Haro, F. J., Guanter, L., Jung, M., Gamon, J. A., Reichstein, M., and Running, S. W.: A unified vegetation index for quantifying the terrestrial biosphere, Science Advances, 7, https://doi.org/10.1126/sciadv.abc7447, 2021.

Cescatti, A., Marcolla, B., Santhana Vannan, S. K., Pan, J. Y., Román, M. O., Yang, X., Ciais, P., Cook, R. B., Law, B. E., Matteucci, G., Migliavacca, M., Moors, E., Richardson, A. D., Seufert, G., and Schaaf, C. B.: Intercomparison of MODIS albedo retrievals and in situ measurements across the global FLUXNET network, Remote Sensing of Environment, 121, 323-334, https://doi.org/https://doi.org/10.1016/j.rse.2012.02.019, 2012.

Chu, H., Luo, X., Ouyang, Z., Chan, W. S., Dengel, S., Biraud, S. C., Torn, M. S., Metzger, S., Kumar, J., Arain, M. A., Arkebauer, T. J., Baldocchi, D., Bernacchi, C., Billesbach, D., Black, T. A., Blanken, P. D., Bohrer, G., Bracho, R., Brown, S., Brunsell, N. A., Chen, J., Chen, X., Clark, K., Desai, A. R., Duman, T., Durden, D., Fares, S., Forbrich, I., Gamon, J. A., Gough, C. M., Griffis, T., Helbig, M., Hollinger, D., Humphreys, E., Ikawa, H., Iwata, H., Ju, Y., Knowles, J. F., Knox, S. H., Kobayashi, H., Kolb, T., Law, B., Lee, X., Litvak, M., Liu, H., Munger, J. W., Noormets, A., Novick, K., Oberbauer, S. F., Oechel, W., Oikawa, P., Papuga, S. A., Pendall, E., Prajapati, P., Prueger, J., Quinton, W. L., Richardson, A. D., Russell, E. S., Scott, R. L., Starr, G., Staebler, R., Stoy, P. C., Stuart-Haëntjens, E., Sonnentag, O., Sullivan, R. C., Suyker, A., Ueyama, M., Vargas, R., Wood, J. D., and Zona, D.: Representativeness of Eddy-Covariance flux footprints for areas surrounding AmeriFlux sites, Agricultural and Forest Meteorology, 301-302, 108 350, https://doi.org/https://doi.org/10.1016/j.agrformet.2021.108350, 2021.

Crosson, W. L., Al-Hamdan, M. Z., Hemmings, S. N., and Wade, G. M.: A daily merged MODIS Aqua-Terra land surface temperature data set for the conterminous United States, Remote Sensing of Environment, 119, 315-324, https://doi.org/https://doi.org/10.1016/j.rse.2011.12.019, 2012.

Drought 2018 Team and ICOS Ecosystem Thematic Centre: Drought-2018 ecosystem eddy covariance flux product for 52 stations in

FLUXNET-Archive format, 2020.

Dumitrescu, A., Brabec, M., and Cheval, S.: Statistical Gap-Filling of SEVIRI Land Surface Temperature, Remote Sensing, 12, https://doi.org/10.3390/rs12091423, 2020. 
https://doi.org/10.5194/bg-2021-314

Preprint. Discussion started: 25 November 2021

(c) Author(s) 2021. CC BY 4.0 License.

(c) (i)

Duveiller, G., Camps-Valls, G., Ceccherini, G., and Cescatti, A.: Spatial homogeneity from temporal stability: Exploiting the combined hyper-frequent revisit of Terra and Aqua to guide Earth System Science, Remote Sensing of Environment, 261, 112496, https://doi.org/https://doi.org/10.1016/j.rse.2021.112496, 2021.

El-Madany, T. S., Reichstein, M., Perez-Priego, O., Carrara, A., Moreno, G., Pilar Martín, M., Pacheco-Labrador, J., Wohlfahrt, G., Nieto, H., Weber, U., Kolle, O., Luo, Y.-P., Carvalhais, N., and Migliavacca, M.: Drivers of spatio-temporal variability of carbon dioxide and energy fluxes in a Mediterranean savanna ecosystem, Agricultural and Forest Meteorology, 262, 258-278, https://doi.org/https://doi.org/10.1016/j.agrformet.2018.07.010, 2018.

540 Ermida, S. L., Trigo, I. F., DaCamara, C. C., Göttsche, F. M., Olesen, F. S., and Hulley, G.: Validation of remotely sensed surface temperature over an oak woodland landscape - The problem of viewing and illumination geometries, Remote Sensing of Environment, 148, 16-27, https://doi.org/https://doi.org/10.1016/j.rse.2014.03.016, 2014.

Ermida, S. L., Trigo, I. F., DaCamara, C. C., and Pires, A. C.: A Methodology to Simulate LST Directional Effects Based on Parametric Models and Landscape Properties, Remote Sensing, 10, https://doi.org/10.3390/rs10071114, 2018.

545 Ermida, S. L., Trigo, I. F., DaCamara, C. C., Jiménez, C., and Prigent, C.: Quantifying the Clear-Sky Bias of Satellite Land Surface Temperature Using Microwave-Based Estimates, Journal of Geophysical Research: Atmospheres, 124, 844-857, https://doi.org/https://doi.org/10.1029/2018JD029354, 2019.

Falge, E., Baldocchi, D., Olson, R., Anthoni, P., Aubinet, M., Bernhofer, C., Burba, G., Ceulemans, R., Clement, R., Dolman, H., Granier, A., Gross, P., Grünwald, T., Hollinger, D., Jensen, N.-O., Katul, G., Keronen, P., Kowalski, A., Ta Lai, C., Law, B. E., Meyers, T., Moncrieff, J., Moors, E., William Munger, J., Pilegaard, K., Üllar Rannik, Rebmann, C., Suyker, A., Tenhunen, J., Tu, K., Verma, S., Vesala, T., Wilson, K., and Wofsy, S.: Gap filling strategies for long term energy flux data sets, Agricultural and Forest Meteorology, 107, 71-77, https://doi.org/https://doi.org/10.1016/S0168-1923(00)00235-5, 2001.

Foga, S., Scaramuzza, P. L., Guo, S., Zhu, Z., Dilley, R. D., Beckmann, T., Schmidt, G. L., Dwyer, J. L., Hughes, M. J., and Laue, B.: Cloud detection algorithm comparison and validation for operational Landsat data products, Remote Sensing of Environment, 194, 379-390, https://doi.org/https://doi.org/10.1016/j.rse.2017.03.026, 2017.

Gamon, J. A.: Reviews and Syntheses: optical sampling of the flux tower footprint, Biogeosciences, 12, 4509-4523, https://doi.org/10.5194/bg-12-4509-2015, 2015.

Gao, B.-c.: NDWI-A normalized difference water index for remote sensing of vegetation liquid water from space, Remote Sensing of Environment, 58, 257-266, https://doi.org/https://doi.org/10.1016/S0034-4257(96)00067-3, 1996.

Gerber, F., de Jong, R., Schaepman, M. E., Schaepman-Strub, G., and Furrer, R.: Predicting Missing Values in Spatio-Temporal Remote Sensing Data, IEEE Transactions on Geoscience and Remote Sensing, 56, 2841-2853, 2018.

Ghafarian Malamiri, H. R., Rousta, I., Olafsson, H., Zare, H., and Zhang, H.: Gap-Filling of MODIS Time Series Land Surface Temperature (LST) Products Using Singular Spectrum Analysis (SSA), Atmosphere, 9, https://doi.org/10.3390/atmos9090334, 2018.

Gitelson, A. A.: Wide Dynamic Range Vegetation Index for Remote Quantification of Biophysical Characteristics of Vegetation, Journal of Plant Physiology, 161, 165-173, https://doi.org/https://doi.org/10.1078/0176-1617-01176, 2004.

Gorelick, N., Hancher, M., Dixon, M., Ilyushchenko, S., Thau, D., and Moore, R.: Google Earth Engine: Planetary-scale geospatial analysis for everyone, Remote Sensing of Environment, https://doi.org/10.1016/j.rse.2017.06.031, 2017.

Guillevic, P. C., Bork-Unkelbach, A., Göttsche, F. M., Hulley, G., Gastellu-Etchegorry, J.-P., Olesen, F. S., and Privette, J. L.: Directional Viewing Effects on Satellite Land Surface Temperature Products Over Sparse Vegetation Canopies-A Multisensor Analysis, IEEE Geoscience and Remote Sensing Letters, 10, 1464-1468, https://doi.org/10.1109/LGRS.2013.2260319, 2013. 
https://doi.org/10.5194/bg-2021-314

Preprint. Discussion started: 25 November 2021

(c) Author(s) 2021. CC BY 4.0 License.

(c) (i)

Huete, A., Didan, K., Miura, T., Rodriguez, E., Gao, X., and Ferreira, L.: Overview of the radiometric and biophysical performance of the MODIS vegetation indices, Remote Sensing of Environment, 83, 195-213, pII: S0034-4257(02)00096-2 ., 2002.

ICOS Ecosystem Thematic Centre and Gebesee: Drought-2018 ecosystem eddy covariance flux product from Gebesee, https://doi.org/10.18160/ZK18-3YW3, 2019.

Joiner, J., Yoshida, Y., Zhang, Y., Duveiller, G., Jung, M., Lyapustin, A., Wang, Y., and Tucker, C. J.: Estimation of Terrestrial Global Gross Primary Production (GPP) with Satellite Data-Driven Models and Eddy Covariance Flux Data, Remote Sensing, 10, https://doi.org/10.3390/rs10091346, 2018.

Jung, M., Koirala, S., Weber, U., Ichii, K., Gans, F., Camps-Valls, G., Papale, D., Schwalm, C., Tramontana, G., and Reichstein, M.: The FLUXCOM ensemble of global land-atmosphere energy fluxes, Scientific Data, 6, https://doi.org/10.1038/s41597-019-0076-8, 2019.

Jung, M., Schwalm, C., Migliavacca, M., Walther, S., Camps-Valls, G., Koirala, S., Anthoni, P., Besnard, S., Bodesheim, P., Carvalhais, N., Chevallier, F., Gans, F., Goll, D. S., Haverd, V., Köhler, P., Ichii, K., Jain, A. K., Liu, J., Lombardozzi, D., Nabel, J. E. M. S., Nelson, J. A., O’Sullivan, M., Pallandt, M., Papale, D., Peters, W., Pongratz, J., Rödenbeck, C., Sitch, S., Tramontana, G., Walker, A., Weber, U., and Reichstein, M.: Scaling carbon fluxes from eddy covariance sites to globe: synthesis and evaluation of the FLUXCOM approach, Biogeosciences, 17, 1343-1365, https://doi.org/10.5194/bg-17-1343-2020, 2020.

Kandasamy, S., Baret, F., Verger, A., Neveux, P., and Weiss, M.: A comparison of methods for smoothing and gap filling time series of remote sensing observations ndash; application to MODIS LAI products, Biogeosciences, 10, 4055-4071, https://doi.org/10.5194/bg-104055-2013, 2013.

Kljun, N., Calanca, P., Rotach, M. W., and Schmid, H. P.: A simple two-dimensional parameterisation for Flux Footprint Prediction (FFP), Geoscientific Model Development, 8, 3695-3713, https://doi.org/10.5194/gmd-8-3695-2015, 2015.

Li, X., Zhou, Y., Asrar, G. R., and Zhu, Z.: Creating a seamless $1 \mathrm{~km}$ resolution daily land surface temperature dataset for urban and surrounding areas in the conterminous United States, Remote Sensing of Environment, 206, 84-97, https://doi.org/https://doi.org/10.1016/j.rse.2017.12.010, 2018.

Luo, Y., El-Madany, T. S., Filippa, G., Ma, X., Ahrens, B., Carrara, A., Gonzalez-Cascon, R., Cremonese, E., Galvagno, M., Hammer, T. W., Pacheco-Labrador, J., Martín, M. P., Moreno, G., Perez-Priego, O., Reichstein, M., Richardson, A. D., Römermann, C., and Migliavacca, M.: Using Near-Infrared-Enabled Digital Repeat Photography to Track Structural and Physiological Phenology in Mediterranean Tree-Grass Ecosystems, Remote Sensing, 10, https://doi.org/10.3390/rs10081293, 2018.

Migliavacca, M., Reichstein, M., Richardson, A. D., Mahecha, M. D., Cremonese, E., Delpierre, N., Galvagno, M., Law, B. E., Wohlfahrt, G., Andrew Black, T., Carvalhais, N., Ceccherini, G., Chen, J., Gobron, N., Koffi, E., William Munger, J., Perez-Priego, O., Robustelli, M., Tomelleri, E., and Cescatti, A.: Influence of physiological phenology on the seasonal pattern of ecosystem respiration in deciduous forests, Global Change Biology, 21, 363-376, https://doi.org/https://doi.org/10.1111/gcb.12671, 2015.

Migliavacca, M., El-Madany, T. S., Carrara, A., Reichstein, M., and ICOS Ecosystem Thematic Centre: Drought-2018 ecosystem eddy covariance flux product from Majadas del Tietar North, https://doi.org/10.18160/FDSD-GVRS, 2020.

Migliavacca, M., Musavi, T., Mahecha, M. D., Nelson, J. A., Knauer, J., Baldocchi, D. D., Perez-Priego, O., Christiansen, R., Peters, J., Anderson, K., Bahn, M., Black, T. A., Blanken, P. D., Bonal, D., Buchmann, N., Caldararu, S., Carrara, A., Carvalhais, N., Cescatti, A., Chen, J., Cleverly, J., Cremonese, E., Desai, A. R., El-Madany, T., Farella, M. M., Fernández-Martínez, M., Filippa, G., Forkel, M., Galvagno, M., Gomarasca, U., Gough, C., Göckede, M., Ibrom, A., Ikawa, H., Janssens, I., Jung, M., Kattge, J., Keenan, T., Knohl, A., Kobayashi, H., Kraemer, G., Law, B. E., Liddell, M., Ma, X., Mammarella, I., Martini, D., Macfarlane, C., Matteucci, G., Montagnani, L., Pabon-Moreno, D., Panigada, C., Papale, D., Pendall, E., Penuelas, J., Phillips, R. P., Reich, P. B., Rossini, M., Rotenberg, E., Scott, 
https://doi.org/10.5194/bg-2021-314

Preprint. Discussion started: 25 November 2021

(c) Author(s) 2021. CC BY 4.0 License.

\section{(c) (i)}

R., Stahl, C., Weber, U., Wohlfahrt, G., Wolf, S., Wright, I., Yakir, D., Zaehle, S., and Reichstein, M.: The three major axes of terrestrial ecosystem function, Nature, 598, https://doi.org/10.1038/s41586-021-03939-9, 2021.

Moffat, A. M., Papale, D., Reichstein, M., Hollinger, D., Richardson, A. D., Barr, A. G., Beckstein, C., Braswell, B. H., Churkina, G., Desai, A. R., Falge, E., Gove, J. H., Heimann, M., Hui, D., Jarvis, A. J., Kattge, J., Noormets, A., and Stauch, V. J.: Comprehensive comparison of gap-filling techniques for eddy covariance net carbon fluxes, Agricultural and Forest Meteorology, 147, 209-232, https://doi.org/https://doi.org/10.1016/j.agrformet.2007.08.011, 2007.

Moreno, A., García-Haro, F. J., Martínez, B., and Gilabert, M. A.: Noise Reduction and Gap Filling of fAPAR Time Series Using an Adapted Local Regression Filter, Remote Sensing, 6, 8238-8260, https://doi.org/10.3390/rs6098238, 2014.

Moreno-Martínez, A., Izquierdo-Verdiguier, E., Maneta, M. P., Camps-Valls, G., Robinson, N., Muñoz-Marí, J., Sedano, F., Clinton, N., and Running, S. W.: Multispectral high resolution sensor fusion for smoothing and gap-filling in the cloud, Remote Sensing of Environment, 247, 111 901, https://doi.org/https://doi.org/10.1016/j.rse.2020.111901, 2020.

Nelson, J. A., Pérez-Priego, O., Zhou, S., Poyatos, R., Zhang, Y., Blanken, P. D., Gimeno, T. E., Wohlfahrt, G., Desai, A. R., Gioli, B., Limousin, J.-M., Bonal, D., Paul-Limoges, E., Scott, R. L., Varlagin, A., Fuchs, K., Montagnani, L., Wolf, S., Delpierre, N., Berveiller, D., Gharun, M., Belelli Marchesini, L., Gianelle, D., Šigut, L., Mammarella, I., Siebicke, L., Andrew Black, T., Knohl, A., Hörtnagl, L., Magliulo, V., Besnard, S., Weber, U., Carvalhais, N., Migliavacca, M., Reichstein, M., and Jung, M.: Ecosystem transpiration and evaporation: Insights from three water flux partitioning methods across FLUXNET sites, Global Change Biology, 26, 6916-6930, https://doi.org/https://doi.org/10.1111/gcb.15314, 2020.

Pacheco-Labrador, J., El-Madany, T. S., Martín, M. P., Migliavacca, M., Rossini, M., Carrara, A., and Zarco-Tejada, P. J.: SpatioTemporal Relationships between Optical Information and Carbon Fluxes in a Mediterranean Tree-Grass Ecosystem, Remote Sensing, 9, https://doi.org/10.3390/rs9060608, 2017.

Papale, D.: Ideas and perspectives: enhancing the impact of the FLUXNET network of eddy covariance sites, Biogeosciences, 17, 5587-5598, https://doi.org/10.5194/bg-17-5587-2020, 2020.

Papale, D., Reichstein, M., Aubinet, M., Canfora, E., Bernhofer, C., Kutsch, W., Longdoz, B., Rambal, S., Valentini, R., Vesala, T., and Yakir, D.: Towards a standardized processing of Net Ecosystem Exchange measured with eddy covariance technique: algorithms and uncertainty estimation, Biogeosciences, 3, 571-583, https://doi.org/10.5194/bg-3-571-2006, 2006.

Pastorello, G., Trotta, C., Canfora, E., Chu, H., Christianson, D., Cheah, Y.-W., Poindexter, C., Chen, J., Elbashandy, A., Humphrey, M., Isaac, P., Polidori, D., Reichstein, M., Ribeca, A., van Ingen, C., Vuichard, N., Zhang, L., Amiro, B., Ammann, C., Arain, M. A., Ardö, J., Arkebauer, T., Arndt, S. K., Arriga, N., Aubinet, M., Aurela, M., Baldocchi, D., Barr, A., Beamesderfer, E., Marchesini, L. B., Bergeron, O., Beringer, J., Bernhofer, C., Berveiller, D., Billesbach, D., Black, T. A., Blanken, P. D., Bohrer, G., Boike, J., Bolstad, P. V., Bonal, D., Bonnefond, J.-M., Bowling, D. R., Bracho, R., Brodeur, J., Brümmer, C., Buchmann, N., Burban, B., Burns, S. P., Buysse, P., Cale, P., Cavagna, M., Cellier, P., Chen, S., Chini, I., Christensen, T. R., Cleverly, J., Collalti, A., Consalvo, C., Cook, B. D., Cook, D., Coursolle, C., Cremonese, E., Curtis, P. S., D’Andrea, E., da Rocha, H., Dai, X., Davis, K. J., Cinti, B. D., Grandcourt, A. d., Ligne, A. D., De Oliveira, R. C., Delpierre, N., Desai, A. R., Di Bella, C. M., Tommasi, P. d., Dolman, H., Domingo, F., Dong, G., Dore, S., Duce, P., Dufrêne, E., Dunn, A., Dušek, J., Eamus, D., Eichelmann, U., ElKhidir, H. A. M., Eugster, W., Ewenz, C. M., Ewers, B., Famulari, D., Fares, S., Feigenwinter, I., Feitz, A., Fensholt, R., Filippa, G., Fischer, M., Frank, J., Galvagno, M., Gharun, M., Gianelle, D., Gielen, B., Gioli, B., Gitelson, A., Goded, I., Goeckede, M., Goldstein, A. H., Gough, C. M., Goulden, M. L., Graf, A., Griebel, A., Gruening, C., Grünwald, 
https://doi.org/10.5194/bg-2021-314

Preprint. Discussion started: 25 November 2021

(c) Author(s) 2021. CC BY 4.0 License.

\section{(c) (i)}

J., Knohl, A., Knox, S., Kobayashi, H., Koerber, G., Kolle, O., Kosugi, Y., Kotani, A., Kowalski, A., Kruijt, B., Kurbatova, J., Kutsch, W. L., Kwon, H., Launiainen, S., Laurila, T., Law, B., Leuning, R., Li, Y., Liddell, M., Limousin, J.-M., Lion, M., Liska, A. J., Lohila, A., López-Ballesteros, A., López-Blanco, E., Loubet, B., Loustau, D., Lucas-Moffat, A., Lüers, J., Ma, S., Macfarlane, C., Magliulo, V., Maier, R., Mammarella, I., Manca, G., Marcolla, B., Margolis, H. A., Marras, S., Massman, W., Mastepanov, M., Matamala, R., Matthes, J. H., Mazzenga, F., McCaughey, H., McHugh, I., McMillan, A. M. S., Merbold, L., Meyer, W., Meyers, T., Miller, S. D., Minerbi, S., Moderow, U., Monson, R. K., Montagnani, L., Moore, C. E., Moors, E., Moreaux, V., Moureaux, C., Munger, J. W., Nakai, T., Neirynck, J., Nesic, Z., Nicolini, G., Noormets, A., Northwood, M., Nosetto, M., Nouvellon, Y., Novick, K., Oechel, W., Olesen, J. E., Ourcival, J.-M., Papuga, S. A., Parmentier, F.-J., Paul-Limoges, E., Pavelka, M., Peichl, M., Pendall, E., Phillips, R. P., Pilegaard, K., Pirk, N., Posse, G., Powell, T., Prasse, H., Prober, S. M., Rambal, S., Rannik, , Raz-Yaseef, N., Rebmann, C., Reed, D., Dios, V. R. d., RestrepoCoupe, N., Reverter, B. R., Roland, M., Sabbatini, S., Sachs, T., Saleska, S. R., Sánchez-Cañete, E. P., Sanchez-Mejia, Z. M., Schmid, H. P., Schmidt, M., Schneider, K., Schrader, F., Schroder, I., Scott, R. L., Sedlák, P., Serrano-Ortíz, P., Shao, C., Shi, P., Shironya, I., Siebicke, L., Šigut, L., Silberstein, R., Sirca, C., Spano, D., Steinbrecher, R., Stevens, R. M., Sturtevant, C., Suyker, A., Tagesson, T., Takanashi, S., Tang, Y., Tapper, N., Thom, J., Tomassucci, M., Tuovinen, J.-P., Urbanski, S., Valentini, R., van der Molen, M., van Gorsel, E., van Huissteden, K., Varlagin, A., Verfaillie, J., Vesala, T., Vincke, C., Vitale, D., Vygodskaya, N., Walker, J. P., Walter-Shea, E., Wang, H., Weber, R., Westermann, S., Wille, C., Wofsy, S., Wohlfahrt, G., Wolf, S., Woodgate, W., Li, Y., Zampedri, R., Zhang, J., Zhou, G., Zona, D., Agarwal, D., Biraud, S., Torn, M., and Papale, D.: The FLUXNET2015 dataset and the ONEFlux processing pipeline for eddy covariance data, Scientific Data, 225, https://doi.org/10.1038/s41597-020-0534-3, 2020.

Rasmussen, M. O., Gottsche, F.-M., Olesen, F.-S., and Sandholt, I.: Directional Effects on Land Surface Temperature Estimation

From Meteosat Second Generation for Savanna Landscapes, IEEE Transactions on Geoscience and Remote Sensing, 49, 4458-4468, https://doi.org/10.1109/TGRS.2011.2144604, 2011.

Reichstein, M., Falge, E., Baldocchi, D., Papale, D., Aubinet, M., Berbigier, P., Bernhofer, C., Buchmann, N., Gilmanov, T., Granier, A., Grünwald, T., Havránková, K., Ilvesniemi, H., Janous, D., Knohl, A., Laurila, T., Lohila, A., Loustau, D., Matteucci, G., Meyers, T., Miglietta, F., Ourcival, J.-M., Pumpanen, J., Rambal, S., Rotenberg, E., Sanz, M., Tenhunen, J., Seufert, G., Vaccari, F., Vesala, T., Yakir, D., and Valentini, R.: On the separation of net ecosystem exchange into assimilation and ecosystem respiration: review and improved algorithm, Global Change Biology, 11, 1424-1439, https://doi.org/https://doi.org/10.1111/j.1365-2486.2005.001002.x, 2005.

Reitz, O., Graf, A., Schmidt, M., Ketzler, G., and Leuchner, M.: Upscaling Net Ecosystem Exchange Over Heterogeneous Landscapes With Machine Learning, Journal of Geophysical Research: Biogeosciences, 126, https://doi.org/https://doi.org/10.1029/2020JG005814, 2021.

Román, M. O., Schaaf, C. B., Woodcock, C. E., Strahler, A. H., Yang, X., Braswell, R. H., Curtis, P. S., Davis, K. J., Dragoni, D., Goulden,

M. L., Gu, L., Hollinger, D. Y., Kolb, T. E., Meyers, T. P., Munger, J. W., Privette, J. L., Richardson, A. D., Wilson, T. B., and Wofsy, S. C.: The MODIS (Collection V005) BRDF/albedo product: Assessment of spatial representativeness over forested landscapes, Remote Sensing of Environment, 113, 2476-2498, https://doi.org/https://doi.org/10.1016/j.rse.2009.07.009, 2009.

Schaaf, C. and Wang, Z.: MCD43A2 MODIS/Terra+Aqua BRDF/Albedo Quality Daily L3 Global - 500m V006, https://doi.org/https://doi.org/10.5067/MODIS/MCD43A2.006, 2015a.

Schaaf, C. and Wang, Z.: MCD43A4 MODIS/Terra+Aqua BRDF/Albedo Nadir BRDF Adjusted Ref Daily L3 Global - 500m V006, https://doi.org/https://doi.org/10.5067/MODIS/MCD43A4.006, 2015b.

Schmid, H.: Experimental design for flux measurements: matching scales of observations and fluxes, Agricultural and Forest Meteorology, 87, 179-200, https://doi.org/https://doi.org/10.1016/S0168-1923(97)00011-7, 1997. 
https://doi.org/10.5194/bg-2021-314

Preprint. Discussion started: 25 November 2021

(c) Author(s) 2021. CC BY 4.0 License.

(c) (i)

Schmidt, G., Jenkerson, C. B., Masek, J., Vermote, E., and Gao, F.: Landsat ecosystem disturbance adaptive processing system (LEDAPS) algorithm description, USGS Publications Warehouse, https://doi.org/10.3133/ofr20131057, 2013.

Stoy, P. C., Mauder, M., Foken, T., Marcolla, B., Boegh, E., Ibrom, A., Arain, M. A., Arneth, A., Aurela, M., Bernhofer, C., Cescatti, A., Dellwik, E., Duce, P., Gianelle, D., van Gorsel, E., Kiely, G., Knohl, A., Margolis, H., McCaughey, H., Merbold, L., Montagnani, L., Papale, D., Reichstein, M., Saunders, M., Serrano-Ortiz, P., Sottocornola, M., Spano, D., Vaccari, F., and Varlagin, A.: A data-driven analysis of energy balance closure across FLUXNET research sites: The role of landscape scale heterogeneity, Agricultural and Forest Meteorology, 171-172, 137-152, https://doi.org/https://doi.org/10.1016/j.agrformet.2012.11.004, 2013.

Tramontana, G., Jung, M., Schwalm, C. R., Ichii, K., Camps-Valls, G., Ráduly, B., Reichstein, M., Arain, M. A., Cescatti, A., Kiely, G., Merbold, L., Serrano-Ortiz, P., Sickert, S., Wolf, S., and Papale, D.: Predicting carbon dioxide and energy fluxes across global FLUXNET sites with regression algorithms, Biogeosciences, 13, 4291-4313, https://doi.org/10.5194/bg-13-4291-2016, 2016.

Tucker, C. J.: Red and photographic infrared linear combinations for monitoring vegetation, Remote sensing of Environment, 8, 127-150, 1979.

Ueyama, M., Ichii, K., Iwata, H., Euskirchen, E., Zona, D., Rocha, A., Harazono, Y., Iwama, C., Nakai, T., and Oechel, W.: Upscaling terrestrial carbon dioxide fluxes in Alaska with satellite remote sensing and support vector regression, Journal of Geophysical Research: Biogeosciences, 118, 1266-1281, https://doi.org/10.1002/jgrg.20095, 2013.

v. Buttlar, J., Zscheischler, J., and Mahecha, M. D.: An extended approach for spatiotemporal gapfilling: dealing with large and systematic gaps in geoscientific datasets, Nonlinear Processes in Geophysics, 21, 203-215, https://doi.org/10.5194/npg-21-203-2014, 2014.

Verger, A., Baret, F., and Weiss, M.: A multisensor fusion approach to improve LAI time series, Remote Sensing of Environment, 115, 2460-2470, https://doi.org/https://doi.org/10.1016/j.rse.2011.05.006, 2011.

Verger, A., Baret, F., Weiss, M., Kandasamy, S., and Vermote, E.: The CACAO Method for Smoothing, Gap Filling, and Characterizing Seasonal Anomalies in Satellite Time Series, IEEE Transactions on Geoscience and Remote Sensing, 51, 1963-1972, https://doi.org/10.1109/TGRS.2012.2228653, 2013.

Vesala, T., Kljun, N., Rannik, , Rinne, J., Sogachev, A., Markkanen, T., Sabelfeld, K., Foken, T., and Leclerc, M.: Flux and concentration footprint modelling: State of the art, Environmental Pollution, 152, 653-666, https://doi.org/https://doi.org/10.1016/j.envpol.2007.06.070, 2008.

Vinnikov, K. Y., Yu, Y., Rama Varma Raja, M. K., Tarpley, D., and Goldberg, M. D.: Diurnal-seasonal and weatherrelated variations of land surface temperature observed from geostationary satellites, Geophysical Research Letters, 35, https://doi.org/https://doi.org/10.1029/2008GL035759, 2008.

Virkkala, A.-M., Aalto, J., Rogers, B. M., Tagesson, T., Treat, C. C., Natali, S. M., Watts, J. D., Potter, S., Lehtonen, A., Mauritz, M., Schuur, E. A. G., Kochendorfer, J., Zona, D., Oechel, W., Kobayashi, H., Humphreys, E., Goeckede, M., Iwata, H., Lafleur, P. M., Euskirchen, E. S., Bokhorst, S., Marushchak, M., Martikainen, P. J., Elberling, B., Voigt, C., Biasi, C., Sonnentag, O., Parmentier, F.-J. W., Ueyama, M., Celis, G., St.Louis, V. L., Emmerton, C. A., Peichl, M., Chi, J., Järveoja, J., Nilsson, M. B., Oberbauer, S. F., Torn, M. S., Park, S.-J., Dolman, H., Mammarella, I., Chae, N., Poyatos, R., López-Blanco, E., Christensen, T. R., Kwon, M. J., Sachs, T., Holl, D., and Luoto, M.: Statistical upscaling of ecosystem $\mathrm{CO} 2$ fluxes across the terrestrial tundra and boreal domain: Regional patterns and uncertainties, Global Change Biology, 27, 4040-4059, https://doi.org/https://doi.org/10.1111/gcb.15659, 2021a.

Virkkala, A.-M., Natali, S. M., Rogers, B. M., Watts, J. D., Savage, K., Connon, S. J., Mauritz, M., Schuur, E. A. G., Peter, D., Minions,

C., Nojeim, J., Commane, R., Emmerton, C. A., Goeckede, M., Helbig, M., Holl, D., Iwata, H., Kobayashi, H., Kolari, P., López-Blanco, E., Marushchak, M. E., Mastepanov, M., Merbold, L., Parmentier, F.-J. W., Peichl, M., Sachs, T., Sonnentag, O., Ueyama, M., Voigt, 
https://doi.org/10.5194/bg-2021-314

Preprint. Discussion started: 25 November 2021

(c) Author(s) 2021. CC BY 4.0 License.

\section{(c) (i)}

C., Aurela, M., Boike, J., Celis, G., Chae, N., Christensen, T. R., Bret-Harte, M. S., Dengel, S., Dolman, H., Edgar, C. W., Elberling, B., Euskirchen, E., Grelle, A., Hatakka, J., Humphreys, E., Järveoja, J., Kotani, A., Kutzbach, L., Laurila, T., Lohila, A., Mammarella, I., Matsuura, Y., Meyer, G., Nilsson, M. B., Oberbauer, S. F., Park, S.-J., Petrov, R., Prokushkin, A. S., Schulze, C., St.Louis, V. L., Tuittila, E.-S., Tuovinen, J.-P., Quinton, W., Varlagin, A., Zona, D., and Zyryanov, V. I.: The ABCflux database: Arctic-Boreal CO ${ }_{2}$ flux observations and ancillary information aggregated to monthly time steps across terrestrial ecosystems, Earth System Science Data Discussions, 2021, 1-54, https://doi.org/10.5194/essd-2021-233, 2021b.

Wagle, P., Gowda, P. H., Neel, J. P., Northup, B. K., and Zhou, Y.: Integrating eddy fluxes and remote sensing products in a rotational grazing native tallgrass prairie pasture, Science of The Total Environment, 712, 136407, https://doi.org/https://doi.org/10.1016/j.scitotenv.2019.136407, 2020.

Walther, S., Besnard, S., Nelson, J. A., El-Madany, T. S., Migliavacca, M., Weber, U., Ermida, S. L., Brümmer, C., Schrader, F., Prokushkin, A. S., Panov, A. V., and Jung, M.: Technical note: A view from space on global flux towers by MODIS and Landsat: The FluxnetEO dataset (Landsat), 2021a.

Walther, S., Besnard, S., Nelson, J. A., El-Madany, T. S., Migliavacca, M., Weber, U., Ermida, S. L., Brümmer, C., Schrader, F., Prokushkin, A. S., Panov, A. V., and Jung, M.: Technical note: A view from space on global flux towers by MODIS and Landsat: The FluxnetEO dataset (MODIS), 2021b.

Wan, Z., Hook, S., and Hulley, G.: MOD11A1 MODIS/Terra Land Surface Temperature/Emissivity Daily L3 Global 1km SIN Grid V006, https://doi.org/https://doi.org/10.5067/MODIS/MOD11A1.006, 2015a.

Wan, Z., Hook, S., and Hulley, G.: MYD11A1 MODIS/Aqua Land Surface Temperature/Emissivity Daily L3 Global 1km SIN Grid V006, https://doi.org/https://doi.org/10.5067/MODIS/MYD11A1.006, 2015b.

Wang, G., Garcia, D., Liu, Y., de Jeu, R., and Johannes Dolman, A.: A three-dimensional gap filling method for large geophysical datasets: Application to global satellite soil moisture observations, Environmental Modelling Software, 30, 139-142, https://doi.org/https://doi.org/10.1016/j.envsoft.2011.10.015, 2012.

Weiss, D. J., Atkinson, P. M., Bhatt, S., Mappin, B., Hay, S. I., and Gething, P. W.: An effective approach for gapfilling continental scale remotely sensed time-series, ISPRS Journal of Photogrammetry and Remote Sensing, 98, 106-118, https://doi.org/https://doi.org/10.1016/j.isprsjprs.2014.10.001, 2014.

Williams, M., Richardson, A. D., Reichstein, M., Stoy, P. C., Peylin, P., Verbeeck, H., Carvalhais, N., Jung, M., Hollinger, D. Y., Kattge, J., Leuning, R., Luo, Y., Tomelleri, E., Trudinger, C. M., and Wang, Y.-P.: Improving land surface models with FLUXNET data, Biogeosciences, 6, 1341-1359, https://doi.org/10.5194/bg-6-1341-2009, 2009.

Wingate, L., Ogée, J., Cremonese, E., Filippa, G., Mizunuma, T., Migliavacca, M., Moisy, C., Wilkinson, M., Moureaux, C., Wohlfahrt, G., Hammerle, A., Hörtnagl, L., Gimeno, C., Porcar-Castell, A., Galvagno, M., Nakaji, T., Morison, J., Kolle, O., Knohl, A., Kutsch, W., Kolari, P., Nikinmaa, E., Ibrom, A., Gielen, B., Eugster, W., Balzarolo, M., Papale, D., Klumpp, K., Köstner, B., Grünwald, T., Joffre, R., Ourcival, J.-M., Hellstrom, M., Lindroth, A., George, C., Longdoz, B., Genty, B., Levula, J., Heinesch, B., Sprintsin, M., Yakir, D., Manise, T., Guyon, D., Ahrends, H., Plaza-Aguilar, A., Guan, J. H., and Grace, J.: Interpreting canopy development and physiology using a European phenology camera network at flux sites, Biogeosciences, 12, 5995-6015, https://doi.org/10.5194/bg-12-5995-2015, 2015.

Wohlfahrt, G., Hammerle, A., Haslwanter, A., Bahn, M., Tappeiner, U., and Cernusca, A.: Seasonal and inter-annual variability of the net ecosystem CO2 exchange of a temperate mountain grassland: Effects of weather and management, Journal of Geophysical Research: Atmospheres, 113, https://doi.org/https://doi.org/10.1029/2007JD009286, 2008. 
https://doi.org/10.5194/bg-2021-314

Preprint. Discussion started: 25 November 2021

(c) Author(s) 2021. CC BY 4.0 License.

(c) (1)

Cohen, W. B., Dwyer, J., Erb, A., Gao, F., Griffiths, P., Helder, D., Hermosilla, T., Hipple, J. D., Hostert, P., Hughes, M. J., Huntington, J., Johnson, D. M., Kennedy, R., Kilic, A., Li, Z., Lymburner, L., McCorkel, J., Pahlevan, N., Scambos, T. A., Schaaf, C., Schott, J. R., Sheng, Y., Storey, J., Vermote, E., Vogelmann, J., White, J. C., Wynne, R. H., and Zhu, Z.: Current status of Landsat program, science, and applications, Remote Sensing of Environment, 225, 127-147, https://doi.org/https://doi.org/10.1016/j.rse.2019.02.015, 2019.

Yan, L. and Roy, D. P.: Large-Area Gap Filling of Landsat Reflectance Time Series by Spectral-Angle-Mapper Based Spatio-Temporal Similarity (SAMSTS), Remote Sensing, 10, https://doi.org/10.3390/rs10040609, 2018.

Zeng, J., Matsunaga, T., Tan, Z.-H., Saigusa, N., Shirai, T., Tang, Y., Peng, S., and Fukuda, Y.: Global terrestrial carbon fluxes of 1999-2019 estimated by upscaling eddy covariance data with a random forest, Scientific Data, 7, https://doi.org/10.1038/s41597-020-00653-5, 2020.

Zhang, J., Shang, R., Rittenhouse, C., Witharana, C., and Zhu, Z.: Evaluating the impacts of models, data density and irregularity on reconstructing and forecasting dense Landsat time series, Science of Remote Sensing, 4, 100023, https://doi.org/https://doi.org/10.1016/j.srs.2021.100023, 2021.

Zhu, Z. and Woodcock, C. E.: Object-based cloud and cloud shadow detection in Landsat imagery, Remote Sensing of Environment, 118, 83-94, https://doi.org/https://doi.org/10.1016/j.rse.2011.10.028, 2012.

Zhu, Z., Wang, S., and Woodcock, C. E.: Improvement and expansion of the Fmask algorithm: cloud, cloud shadow, and snow detection for Landsats 4-7, 8, and Sentinel 2 images, Remote Sensing of Environment, 159, 269-277, https://doi.org/https://doi.org/10.1016/j.rse.2014.12.014, 2015. 